ISSN: 2146-3042

DOI: $10.25095 /$ mufad.607194

\title{
Uluslararası Kamu Sektörü Muhasebe Standartları (IPSAS): Genel Bakış ve IFRS'lerden Farklılığı
}

\author{
Elif UMUT ${ }^{* *}$ \\ Can ÖZTÜRK ${ }^{* * *}$
}

\section{ÖZET}

Uluslararası Kamu Sektörü Muhasebe Standartları Kurulu (IPSASB) tarafindan hazırlanan Uluslararası Kamu Sektörü Muhasebe Standartları (IPSAS) bu çalışmanın odak noktasını oluşturmaktadır. Çalışmada tam tahakkuk esasına dayanan IPSAS setinin kapsamı, hazırlanmasında izlenen yol, IPSAS'lar ve IPSAS benzeri standartları benimseyen ülkeler üzerinde durulmuş ve IFRS'lerden farkları temel olarak ortaya konmuştur. Çalışmada, IPSAS'ların esas alındiğ IFRS metinlerinin son sürümleri çerçevesinde güncellenerek kamu sektörüne özel hükümler dlşında IFRS'e benzer hükümler benimsenmesi neticesinde mali tablo hazırlayıcıların yükünün azaltılması önerilmiştir.

Anahtar Kelimeler: Devlet Muhasebesi, IPSAS, IPSASB, IFRS

Jel Sinıflandırmasi: M40, M41, M48

\section{International Public Sector Accounting Standards (IPSAS): An Overview \& Their} Differences from IFRS

\section{ABSTRACT}

This paper focuses on International Public Sector Accounting Standards (IPSAS) that are prepared by International Public Sector Accounting Standards Board (IPSASB). In this study, the coverage of IPSAS that is based on full accrual basis, the road map to prepare IPSAS standards, IPSAS or similar standards adopted countries are declared and essential differences between IPSAS and IFRS were examined. This paper proposes the updating of the texts of IPSAS in the context of the most recent version of IFRS and adoption of similar IFRS policies except for public sector-specific issues to decrease the burden experienced by the preparers of financial statements.

KeyWords: Governmental Accounting, IPSAS, IPSASB, IFRS

Jel Classification: M40, M41, M48

Makale Gönderim Tarihi: 01.06.2019

Makale Kabul Tarihi: 01.08.2019

Makale Türü: Kuramsal (Teorik) Makale

\footnotetext{
* Bu çalışma, 1-4 Mayıs 2019 tarihlerinde Bursa'da düzenlenen V. Uluslararası Muhasebe ve Finans Sempozyumu'nda özet bildiri olarak sunulmuştur.

** Lec.Phd.,Başkent Üniversitesi, İktisadi ve İdari Bilimler Fakültesi, İşletme Bölümü, esarman@baskent.edu.tr, orcid.org/0000-0002-7755-6790

*** Associate Prof.,Çankaya Üniversitesi, İktisadi ve İdari Bilimler Fakültesi, İşletme Bölümü, cozturk@cankaya.edu.tr, orcid.org/0000-0003-1587-4707
} 


\section{GİRiş}

Kamu sektörü de, özel sektörde olduğu gibi risksiz değildir. Dolayısıyla, kamu sektöründe mali yönetimin başarısız olması aynı zamanda ekonomik başarısızlığa da neden olabileceğinden söz konusu olumsuzlukların özel sektöre yansıması sonucunda özel sektörde de pek çok kurumsal başarısızlık beklenebilir (IPSASB, 2018a). Bir başka deyişle, kamu sektöründe yaşanan olumsuzluklar nedeniyle kamu sektöründe hazırlanan finansal tabloların daha güvenilir ve şeffaf olmasına duyulan ihtiyaç, d iğer taraftan hükümetlerin sahip oldukları kaynakları günden güne azaltan küresel finansal krizlerin etkisiyle de daha yoğun olarak hissedilmeye başlanmıştır. Bu doğrultuda, bazı ülkelerde kamu sektörü için nakit esaslı olarak hazırlanan mali tablolar ve dipnotlardaki bilgiler likidite krizini öngörmek ya da önlemek için çaba harcayan bu ülkeler açısından yetersiz kalmıştır (ACCA,2017).

Kamu sektörü mali tablolarının gerek ihtiyaca uygun, tam, tarafsız ve önemli bilgiyi sağlaması gerekse ülkeler arası karşılaştırılabilir olarak hazırlanabilmesinin yegane koşulu mali tabloların ortak bir kural setine tabi olmasıdır. Bu kapsamda, Uluslararası Kamu Sektörü Muhasebe Standartları (IPSAS) küresel olarak gün geçtikçe kabul edilirliği artan bir uygulama olarak gündemde yer almaktadır. Dolayısıyla, IPSAS'ların benimsenmesi ve genel kabul görmesi sayesinde karşılaştırılabilir mali tabloların üretilmesi ülkeler arasındaki finansal sınırların genişlemesi anlamında oldukça yararlıdır. IPSAS'larda benimsenen tahakkuk esaslı muhasebe uygulaması, finansal duruma ilişkin daha kapsamlı ve geçerli bir bakış açısı sunduğu ve hükümet ile diğer kamu sektörü kuruluşlarının mali tablolarının şeffaflık ve güvenilirliğini sağladığı için "güçlü muhasebe ve raporlamanın" temel ilkesini oluşturmaktadır (Aggestam-Pontoppidan ve Anderneck, 2015).

$\mathrm{Bu}$ doğrultuda; çalışmanın amacı; (1) IPSAS'ların kapsamını ortaya koymak ve hazırlanmasında izlenen yolu ve de benimsenmesinin getireceği faydaları değerlendirmek, (2) IPSAS'ların Avrupa Birliğine üye ülkeler, Avrupa Birliği ülkeleri dışındaki dünya ülkeleri ve Uluslararası Kuruluşlar ve Birleşmiş Milletler Örgütleri tarafından benimsenmesi ve uygulanması sürecini ortaya koymak ve (3) IPSAS'ların temelini oluşturan Uluslararası Finansal Raporlama Standartları (IFRS) ile karşılaştırarak her iki standart seti arasında benzerlik ve farklılıkları temel açıdan ortaya koymaktır.

Çalışma giriş kısmını takiben beş bölümden oluşmaktadır. İkinci bölümde, devlet muhasebesi kayıtlarında kullanılan yöntemlere değinilmiştir. Üçüncü bölümde IPSAS standart setine, standartların hazırlanmasında izlenen yola, IPSAS'lar hazırlanırken esas alındığı IFRS'lerin neler olduğuna, IPSAS'ları uygulayacak kamu sektörü işletmeleri tanımına ve de IPSAS'ları benimsemenin sağlayacağı faydalara değinilmiştir. Dördüncü bölümde Avrupa Birliği(AB) ülkeleri, $\mathrm{AB}$ ülkeleri dışındaki dünya ülkeleri ile uluslararası kuruluşlar ve Birleşmiş Milletler Örgütlerinin IPSAS'ları benimseme durumları değerlendirilmiştir. Beşinci bölümde IPSAS'ların IFRS'lerden farkları temel açılardan ortaya konmuştur. Altıncı ve son bölümde ise IPSAS'larla ilgili genel bir değerlendirmede bulunulmuştur. 


\section{DEVLET MUHASEBESI KAYITLARINDA KULLANILAN YÖNTEMLER AÇISINDAN DEVLET MUHASEBESINIIN SINIFLANDIRILMASI}

Her ne kadar yukarıda IPSAS'lar ve dayandığı tam tahakkuk sisteminin kamu sektörü mali tablolarının gerçeğe uygun sunumu sağlaması açısından önem arz ettiği belirtilmiş olmakla birlikte devlet muhasebesi kayıtlarında kullanılan yöntemler tam tahakkuk esası ile birlikte 4 adettir. Bunlar; (1) tam tahakkuk esası, (2) uyarlanmış tahakkuk esası, (3) nakit esası ve (4) uyarlanmış nakit esasıdır. Söz konusu yöntemler, izleyen bölümlerde sözü edilen ülke uygulamalarının anlaşılması açısından aşağıda kısaca açıklanmıştır.

\subsection{Tam Tahakkuk Esası}

Tahakkuk esasına göre işlemler ve olaylar, yaratacakları nakit giriş ve çıkışlarının ne zaman olacağına bakılmaksızın, ortaya çıktıklarında kaydedilmektedir (Karaarslan, 2005: 16). $\mathrm{Bu}$ bağlamda, gelirler hesabı, nakit olarak tahsil edilip edilmediklerine bakılmaksızın, ilgili mali yıl boyunca meydana gelen gelir işlemlerini göstermekte olup, diğer taraftan; giderler hesabı da, nakit olarak ödenip ödenmediklerine bakılmaksızın, ilgili mali yıl boyunca doğan giderleri raporlar. Dolayısıyla, kamu sektörü mali tabloları raporladıkları faaliyet dönemine ait mali işlemleri tam olarak yansıtmaktadırlar.

Tahakkuk esasına göre raporlamanın bir diğer özelliği ise üretilen mali raporların, kamu sektörüne ait gelirleri, giderleri (amortisman dahil), varlıkları (mali ve fiziksel varlıkları, cari ve sermaye varlıklarını), yükümlülükleri ve diğer ekonomik akımları tam olarak içermekte olmasıdır. Bu doğrultuda yapılan raporlama, kamu kaynaklarının etkin, verimli ve ekonomik kullanılıp kullanılmadığını ya da diğer bir ifade ile kamu yöneticilerinin performanslarının yani iyi yönetici olup olmadıklarının ölçümünde sağlam bir alt yapı oluşturarak kamu sektörü işletmelerinin finansal durumu, finansal performansı ve nakit akışları hakkında kapsamlı bir fotoğraf alınmasını sağlamaktadır (Karaarslan, 2004: 43).

\subsection{Uyarlanmış Tahakkuk Esası}

Uyarlanmış tahakkuk esası, tam tahakkuk esası ile benzerlik göstermektedir. Tam tahakkuk sisteminde olduğu gibi işlemler ve olaylar, nakit giriş ve çıkışlarının ne zaman olduğuna bakılmaksızın, bir ekonomik değer yaratıldığında, değişime uğradığında, mübadeleye konu edildiğinde, devredildiğinde veya yok olduğunda kaydedilmektedir (Karaarslan, 2005: 15).

Diğer taraftan, uyarlanmış tahakkuk esasını tam tahakkuk esasından farklı kılan özellikler de bulunmaktadır. Bu esasa göre arsa, arazi, bina, taşıtlar, demirbaşlar, ormanlar, anıtlar gibi maddi duran varlıklara ilişkin işlemler muhasebe sistemine dahil edilmediği ve raporlanmadığı için maddi duran varlıkların tespiti, amortisman ayrılması ve yeniden değerlemeye tabi tutulması gibi işlemler söz konusu değildir (Gökçen, 2003: 25; Karaarslan 2005: 15).

\subsection{Nakit Esası}

Nakit esasına göre mali işlemler ve olaylar nakit girişi veya çıkışı yarattığında muhasebeleştirilir (Karaarslan, 2005: 13). Dolayısıyla, bu yöntemde tahakkuk esasında 
olduğu gibi işlemlerden sağlanan hizmet ve faydaların ne zaman ortaya çıktığı dikkate alınmaz. Bu yönteme göre hazırlanan mali raporlar, esasen bütçe gelir tahminlerini ve gider tahminlerini, nakit girişlerini, nakit çıkışlarını, açılış ve kapanış nakit varlıklarını raporlar. $\mathrm{Bu}$ doğrultuda, devletin sahip olduğu, özellikle maddi duran varlıklara, tahakkuk etmiş gelir ve giderlere, aktifleştirilmesi gereken varlıklara yapılan harcamalara, devlet borçları ile diğer yükümlülüklere, taahhüt ve garantiler ile varlık ve yükümlülüklere ilişkin fiyat ve miktar değişmelerine ilişkin durumlar kaydedilmediği ve raporlanmadığı için muhasebe sisteminin kapsadığı işlemler nakit akımları ile sınırlı kalmaktadır. Bu çerçevede, tam tahakkuk sistemi ile karşılaştırıldığında kamu sektörü mali tablolarının şeffaflık ve hesap verilebilirlilik amaçlarına fazla hizmet etmemektedir (Karaarslan, 2005: 14).

\subsection{Uyarlanmış Nakit Esası}

Uyarlanmış nakit esasına göre mali olaylar ve işlemler ilgili oldukları ve sonuçlarının alındığı dönemlere bakılmaksızın nakit olarak tahsil edildikleri veya ödendikleri zaman kaydedilir (Karaarslan, 2005: 14). Bu sistemde de, nakit esasında olduğu gibi, özellikle maddi duran varlıklar, yükümlülükler, taahhüt ve garantiler ve borç yönetimine ilişkin işlemler muhasebeleştirilmezler.

Diğer taraftan, uyarlanmış nakit esasını, nakit esasından ayıran en önemli özellik; muhasebe işlemlerinin mali yılın son günü akşamı itibariyle kapatılmayarak genellikle bir ay süresince açık tutulması neticesinde dönemsellik ilkesi esas alınarak önceki mali yıla ilişkin işlemlerin ait oldukları mali yılın muhasebe kayıtlarına dahil edilerek ilgili mali döneme ait mali tablolarda raporlanmasının sağlanıyor olmasıdır (Gökçen, 2003: 25).

\section{ULUSLARARASI KAMU SEKTÖRÜ MUHASEBE STANDARTLARI}

\subsection{IPSAS Setinin Kapsamı}

Uluslararası Kamu Sektörü Muhasebe Standartları Kurulu (IPSASB) tarafindan hazırlanan tahakkuk esasına dayalı IPSAS'lar Mart 2019 tarihi itibariyle 42 adet standarttan oluşmakta olup aşağıda Tablo 1'de listelenmiştir.

\subsection{IPSAS'ların Hazırlanmasında İzlenen Yol}

IPSASB tarafından tahakkuk esasına dayanan IPSAS'lar geliştirilirken kamu sektörü finansal raporlamasına ilişkin hususlar ele alınmıştır (IPSASB,2018b). Bu doğrultuda, aşağıdaki yol izlenmiştir:

(1) Halihazırda yürürlükte olan IFRS'lerde bugüne değin kapsamlı ve en uygun biçimde yer almamış ve değinilmemiş hususlar ile kamu sektörüne ilişkin bir hususu belirten hiçbir IFRS olmadığı haller de IPSASB tarafından özel bir IPSAS üretilmiştir. Bu bağlamda; Tablo 1'de görüldüğü gibi IPSAS 22, IPSAS 23, IPSAS 24 ve IPSAS 42 bu kapsama giren standartlar olma özelliği göstermektedir.

(2) IPSAS'lar esasen kamu sektörüne uyarlanmış IFRS'leri oluşturmaktadır. Bu nedenle, yukarıda madde 1'de belirtilen durumlar söz konusu olmadıkça IFRS metinlerinden faydalanarak IFRS uygulamaları ile birbirine yakınsak olacak nitelikte IPSAS'lar geliştirmek 
hedeflenmiştir. Dolayısıyla, IFRS metinleri esas alınıp kamu sektörüne uyarlanmıştır. Bu bağlamda, özel üretilen IPSAS'lar dışındaki standartlarda hem IFRS hem de kamu sektörü yansımalarını görmek mümkündür. Bu hususla ilgili olarak Tablo 1'de IPSAS metinlerinin dayandığg IFRS'ler gösterilmiştir.

Ayrıca, söz konusu tabloda "uyum statüsü” sütununda IPSAS'ların Mart 2019 tarihi itibariyle IFRS'lerden etkilenme durumları ve ne oranda kamu sektörünün etkisini yansıttığı ifade edilmiştir.

Tablo 1. Mart 2019 İtibariyle IPSAS'lar ve Dayandığı IFRS'ler

\begin{tabular}{|c|c|c|}
\hline IPSAS & IFRS & Uyum Statüsü \\
\hline IPSAS 1 Mali Tabloların Sunuluşu & IAS 1 & $\begin{array}{l}\text {-Belli düzeyde IFRS yönlendirmesi içeren kamu } \\
\text { sektörüne özgü bir IPSAS'tır. Aktif bir proje kapsamında } \\
\text { IAS 1'deki değişiklikler henüz dikkate alınmamıştır. }\end{array}$ \\
\hline IPSAS 2 Nakit Akış Tabloları & IAS 2 & $\begin{array}{l}\text {-Kamu sektörü yönlendirmesi bulunan bir IPSAS'tır } \\
\text { (Kamu sektörü terminolojisi ve değişiklikler). Aktif bir } \\
\text { proje kapsamında IAS 7'deki değişiklikler henüz dikkate } \\
\text { alınmamıştır. }\end{array}$ \\
\hline $\begin{array}{l}\text { IPSAS } 3 \text { Muhasebe Politikaları, } \\
\text { Muhasebe Tahminlerindeki } \\
\text { Değişiklikler ve Hatalar }\end{array}$ & IAS 8 & $\begin{array}{l}\text {-Kamu sektörü yönlendirmesi bulunan bir IPSAS’tır } \\
\text { (Kamu sektörü terminolojisi ve değişiklikler). IAS 8'deki } \\
\text { değişiklikler cari bir proje kapsamında dikkate } \\
\text { alınacaktır. }\end{array}$ \\
\hline $\begin{array}{l}\text { IPSAS } 4 \text { Döviz Kurlarındaki } \\
\text { Değişikliklerin Etkileri }\end{array}$ & IAS 21 & $\begin{array}{l}\text {-Önemsiz düzeyde kamu sektörü yönlendirmesi bulunan } \\
\text { bir IPSAS’tır (Kamu sektörü terminolojisi ve önemsiz } \\
\text { düzeyde değişiklik). IAS } 21 \text { 'deki değişiklikler cari bir } \\
\text { proje kapsamında dikkate alınacaktır. }\end{array}$ \\
\hline IPSAS 5 Borçlanma Maliyetleri & IAS 23 & $\begin{array}{l}\text {-Kamu sektörü yönlendirmesi bulunan bir IPSAS'tır } \\
\text { (Kamu sektörü terminolojisi ve değişiklikler). IAS } \\
\text { 23'deki değişiklikler cari bir proje kapsamında dikkate } \\
\text { alınacaktır. }\end{array}$ \\
\hline $\begin{array}{l}\text { IPSAS } 9 \text { Bedel Karşıllı̆̆ Olan } \\
\text { Faaliyetlerden Hasılat }\end{array}$ & IAS 18 & $\begin{array}{l}\text {-Önemsiz düzeyde kamu sektörü yönlendirmesi bulunan } \\
\text { bir IPSAS’tı̆ (Kamu sektörü terminolojisi ve önemsiz } \\
\text { düzeyde değişiklik). Cari bir proje kapsamında yeni } \\
\text { IFRS olan IFRS } 15 \text { dikkate alınacaktır. }\end{array}$ \\
\hline $\begin{array}{l}\text { IPSAS } 10 \text { Yüksek Enflasyonlu } \\
\text { Ekonomilerde Finansal Raporlama }\end{array}$ & IAS 29 & $\begin{array}{l}\text {-Önemsiz düzeyde kamu sektörü yönlendirmesi bulunan } \\
\text { bir IPSAS’tır (Kamu sektörü terminolojisi ve önemsiz } \\
\text { düzeyde değişiklik). Güncellenmiştir. }\end{array}$ \\
\hline IPSAS 11 İnşaat Sözleşmeleri & IAS 18 & $\begin{array}{l}\text {-Kamu sektörü yönlendirmesi bulunan bir IPSAS'tır } \\
\text { (Kamu sektörü terminolojisi ve değişiklikler). Cari bir } \\
\text { proje kapsamında yeni IFRS olan IFRS } 15 \text { dikkate } \\
\text { alınacaktır. }\end{array}$ \\
\hline IPSAS 12 Stoklar & IAS 2 & $\begin{array}{l}\text {-Kamu sektörü yönlendirmesi bulunan bir IPSAS'tır } \\
\text { (Kamu sektörü terminolojisi ve değişiklikler). Aktif bir } \\
\text { proje kapsamında IAS 2'deki değişiklikler henüz dikkate } \\
\text { alınmamıştır. }\end{array}$ \\
\hline IPSAS 13 Kiralamalar & IAS 17 & $\begin{array}{l}\text {-Kamu sektörü yönlendirmesi bulunan bir IPSAS'tır } \\
\text { (Kamu sektörü terminolojisi ve değişiklikler). Cari bir } \\
\text { proje kapsamında yeni IFRS olan IFRS } 16 \text { dikkate } \\
\text { alınacaktır. }\end{array}$ \\
\hline $\begin{array}{l}\text { IPSAS } 14 \text { Raporlama Tarihinden } \\
\text { Sonraki Olaylar }\end{array}$ & IAS 10 & $\begin{array}{l}\text {-Kamu sektörü yönlendirmesi bulunan bir IPSAS'tır } \\
\text { (Kamu sektörü terminolojisi ve değişiklikler). IAS } \\
\text { 10'daki değişiklikler cari bir proje kapsamında dikkate } \\
\text { alınacaktır. }\end{array}$ \\
\hline
\end{tabular}




\begin{tabular}{|c|c|c|}
\hline $\begin{array}{l}\text { IPSAS } 16 \text { Yatırım Amaçlı } \\
\text { Gayrimenkuller }\end{array}$ & IAS 40 & $\begin{array}{l}\text {-Kamu sektörü yönlendirmesi bulunan bir } \\
\text { IPSAS'tır(Kamu sektörü terminolojisi ve değişiklikler). } \\
\text { IAS 40'daki değişiklikler cari bir proje kapsamında } \\
\text { dikkate alınacaktır. }\end{array}$ \\
\hline IPSAS 17 Maddi Duran Varlıklar & IAS 16 & $\begin{array}{l}\text {-Kamu sektörü yönlendirmesi bulunan bir IPSAS'tır } \\
\text { (Kamu sektörü terminolojisi ve değişiklikler). IAS } \\
\text { 16'daki değişiklikler cari bir proje kapsamında dikkate } \\
\text { alınacaktır. }\end{array}$ \\
\hline $\begin{array}{l}\text { IPSAS } 18 \text { Bölümlere Göre } \\
\text { Raporlama }\end{array}$ & IAS 14 & $\begin{array}{l}\text {-Kamu sektörü yönlendirmesi bulunan bir IPSAS’tır } \\
\text { (Kamu sektörü terminolojisi ve değişiklikler). Yeni IFRS } \\
\text { olan IFRS } 8 \text { ile gelen değişiklikler aktif bir proje } \\
\text { kapsamında henüz dikkate alınmamıştır. }\end{array}$ \\
\hline $\begin{array}{l}\text { IPSAS } 19 \text { Karşı1ıklar,Koşullu Borçlar } \\
\text { ve Koşullu Varlıklar }\end{array}$ & IAS 37 & $\begin{array}{l}\text {-Kamu sektörü yönlendirmesi bulunan bir IPSAS'tır } \\
\text { (Kamu sektörü terminolojisi ve değişiklikler). IAS } \\
\text { 37'deki değişiklikler cari bir proje kapsamında dikkate } \\
\text { alınacaktır. }\end{array}$ \\
\hline IPSAS 20 İlişkili Taraf Açıklamaları & IAS 24 & $\begin{array}{l}\text {-Belli düzeyde IFRS yönlendirmesi içeren kamu } \\
\text { sektörüne özgü bir IPSAS'tır. IAS 24'deki değişiklikler } \\
\text { aktif bir proje kapsamında henüz dikkate alınmamıştır. }\end{array}$ \\
\hline $\begin{array}{l}\text { IPSAS } 21 \text { Nakit Üretmeyen } \\
\text { Varlıklarda Değer Düşüklüğü }\end{array}$ & IAS 36 & $\begin{array}{l}\text {-Belli düzeyde IFRS yönlendirmesi içeren kamu } \\
\text { sektörüne özgü bir IPSAS'tır. IAS 36'daki değişiklikler } \\
\text { aktif bir proje kapsamında henüz dikkate alınmamıştır. }\end{array}$ \\
\hline $\begin{array}{l}\text { IPSAS } 22 \text { Genel Kamu Sektöründeki } \\
\text { Finansal Bilginin Açıklanması }\end{array}$ & - & -Kamu sektörüne özgü bir IPSAS’tır. \\
\hline $\begin{array}{l}\text { IPSAS } 23 \text { Bedel Karşı1lığ } \text { Olmayan } \\
\text { İşlemlerden Faaliyetlerden } \\
\text { Kaynaklanan Hasılat }\end{array}$ & - & -Kamu sektörüne özgü bir IPSAS’tır. \\
\hline $\begin{array}{l}\text { IPSAS } 24 \text { Finansal Tablolarda } \\
\text { Bütçeye İlişkin Bilgilerin Sunulması }\end{array}$ & - & -Kamu sektörüne özgü bir IPSAS'tır. \\
\hline $\begin{array}{l}\text { IPSAS } 26 \text { Nakit Üreten Varlıklarda } \\
\text { Değer Düşüklüğü }\end{array}$ & IAS 36 & $\begin{array}{l}\text {-Kamu sektörü yönlendirmesi bulunan bir IPSAS'tır } \\
\text { (Kamu sektörü terminolojisi ve değişiklikler). Aktif bir } \\
\text { proje kapsamında IAS 36'daki değişiklikler henüz } \\
\text { dikkate alınmamıştır. }\end{array}$ \\
\hline IPSAS 27 Tarımsal Faaliyetler & IAS 41 & $\begin{array}{l}\text {-Kamu sektörü yönlendirmesi bulunan bir IPSAS'tır } \\
\text { (Kamu sektörü terminolojisi ve değişiklikler). IAS } \\
41 \text { 'deki değişiklikler cari bir proje kapsamında dikkate } \\
\text { alınacaktır. }\end{array}$ \\
\hline IPSAS 28 Finansal Araçlar: Sunum & $\begin{array}{l}\text { IAS 32, } \\
\text { IFRIC } 2\end{array}$ & $\begin{array}{l}\text {-Kamu sektörü yönlendirmesi bulunan bir IPSAS'tır } \\
\text { (Kamu sektörü terminolojisi ve değişiklikler). IAS } \\
\text { 32'daki değişiklikler cari bir proje kapsamında dikkate } \\
\text { alınacaktır. }\end{array}$ \\
\hline $\begin{array}{l}\text { IPSAS } 29 \text { Finansal Araçlar: } \\
\text { Muhasebeleştirme ve Ölçme }\end{array}$ & $\begin{array}{l}\text { IAS 39, } \\
\text { IFRIC } 16\end{array}$ & $\begin{array}{l}\text {-Kamu sektörü yönlendirmesi bulunan bir IPSAS'tır } \\
\text { (Kamu sektörü terminolojisi ve değişiklikler). IAS } \\
\text { 39'daki değişiklikler cari bir proje kapsamında dikkate } \\
\text { alınacaktır. }\end{array}$ \\
\hline $\begin{array}{l}\text { IPSAS } 30 \text { Finansal Araçlar: } \\
\text { Açıklamalar }\end{array}$ & IFRS 7 & $\begin{array}{l}\text {-Kamu sektörü yönlendirmesi bulunan bir IPSAS'tır } \\
\text { (Kamu sektörü terminolojisi ve değişiklikler). IFRS } \\
\text { 7'deki değişiklikler cari bir proje kapsamında dikkate } \\
\text { alınacaktır. }\end{array}$ \\
\hline $\begin{array}{l}\text { IPSAS } 3 \text { Maddi Olmayan Duran } \\
\text { Varlıklar }\end{array}$ & $\begin{array}{l}\text { IAS 38, SIC } \\
32\end{array}$ & $\begin{array}{l}\text {-Kamu sektörü yönlendirmesi bulunan bir IPSAS'tır } \\
\text { (Kamu sektörü terminolojisi ve değişiklikler). IAS } \\
\text { 38'deki değişiklikler cari bir proje kapsamında dikkate } \\
\text { alınacaktır. }\end{array}$ \\
\hline
\end{tabular}




\begin{tabular}{|c|c|c|}
\hline $\begin{array}{l}\text { IPSAS } 32 \text { İmtiyazlı Hizmet } \\
\text { Anlaşmaları: Hibe/BağışYapan }\end{array}$ & $\begin{array}{l}\text { IFRIC } 12, \\
\text { SIC } 29\end{array}$ & $\begin{array}{l}\text {-Belli düzeyde IFRS yönlendirmesi içeren kamu } \\
\text { sektörüne özgü bir IPSAS'tır. İlgili IAS/IFRS'lerdeki } \\
\text { değişiklikler cari bir proje kapsamında dikkate } \\
\text { alınacaktır. }\end{array}$ \\
\hline $\begin{array}{l}\text { IPSAS } 33 \text { Tahakkuk Esaslı } \\
\text { IPSAS'ların İlk Uygulaması }\end{array}$ & IFRS 1 & $\begin{array}{l}\text {-Belli düzeyde IFRS yönlendirmesi içeren kamu } \\
\text { sektörüne özgü bir IPSAS'tır. IFRS 1'deki değişiklikler } \\
\text { cari bir proje kapsamında dikkate alınacaktır. }\end{array}$ \\
\hline IPSAS 34 Bireysel Finansal Tablolar & IAS 27 & $\begin{array}{l}\text {-Kamu sektörü yönlendirmesi bulunan bir IPSAS'tır } \\
\text { (Kamu sektörü terminolojisi ve değişiklikler). } \\
\text { Güncellenmiştir. }\end{array}$ \\
\hline $\begin{array}{l}\text { IPSAS } 35 \text { Konsolide Finansal } \\
\text { Tablolar }\end{array}$ & IFRS 10 & 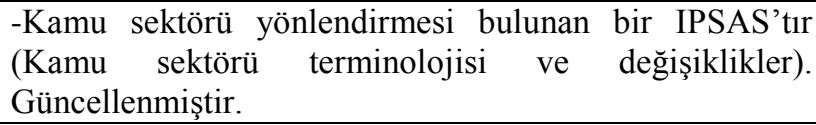 \\
\hline $\begin{array}{l}\text { IPSAS } 36 \text { İştirakler ve İş } \\
\text { Ortaklıklarındaki Yatırımlar }\end{array}$ & IAS 28 & $\begin{array}{l}\text {-Kamu sektörü yönlendirmesi bulunan bir IPSAS'tır } \\
\text { (Kamu sektörü terminolojisi ve değişiklikler). } \\
\text { Güncellenmiştir. }\end{array}$ \\
\hline IPSAS 37 Müşterek Anlaşmalar & IFRS 11 & 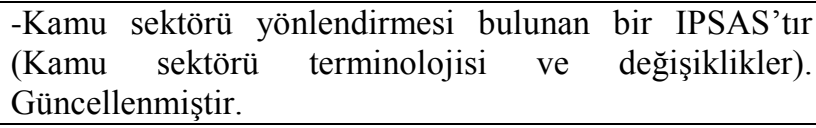 \\
\hline $\begin{array}{l}\text { IPSAS } 38 \text { Diğer Kuruluşlardaki } \\
\text { Paylara İlişkin Açıklamalar }\end{array}$ & IFRS 12 & $\begin{array}{l}\text {-Kamu sektörü yönlendirmesi bulunan bir IPSAS'tır } \\
\text { (Kamu sektörü terminolojisi ve } \\
\text { Güncellenmiştir. }\end{array}$ \\
\hline $\begin{array}{l}\text { IPSAS } 39 \text { Çalışanlara Sağlanan } \\
\text { Faydalar }\end{array}$ & IAS 19 & 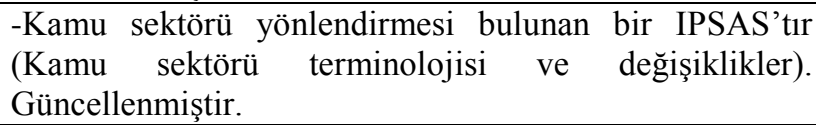 \\
\hline IPSAS 40 Kamu Sektörü Birleşmeleri & IFRS 3 & $\begin{array}{l}\text {-Belli düzeyde IFRS yönlendirmesi içeren kamu } \\
\text { sektörüne özgü bir IPSAS'tır. IFRS 3'deki değişiklikler } \\
\text { cari bir proje kapsamında dikkate alınacaktır. }\end{array}$ \\
\hline IPSAS 41 Finansal Araçlar & $\begin{array}{l}\text { IFRS 9, } \\
\text { IFRIC } 16\end{array}$ & $\begin{array}{l}\text {-Kamu sektörü yönlendirmesi bulunan bir IPSAS'tır } \\
\text { (Kamu sektörü terminolojisi ve değişiklikler). İlgili } \\
\text { IAS/IFRS'lerdeki değişiklikler cari bir proje kapsamında } \\
\text { dikkate alınacaktır. }\end{array}$ \\
\hline IPSAS 42 Sosyal Faydalar & - & -Kamu sektörüne özgü bir IPSAS'tır. \\
\hline
\end{tabular}

Kaynak: IPSASB (2019) IPSASB Meeting (March 2019) IPSAS - IFRS Alignment Dashboard'dan uyarlanmıştır.

\subsection{IPSAS’ları Uygulayacak Kamu Sektörü Kuruluşları ve Temel Özellikleri}

Merkezi Kanada'da bulunan Kamu Sektörü Muhasebe Kurulu (Public Sector Accounting Board - PSAB) (2011) ve IPSASB (2011) tarafından kamu sektörü kuruluşlarının temel özellikleri aşağıdaki biçimde belirlenmiştir:

(1) Kamu sorumluluğu: Hükümetler demokratik birtakım süreçler neticesinde seçilmiş oldukları için kamuya ve seçilmiş temsilcilerine karşı büyük sorumlulukları bulunmaktadır. Kamu sorumluluğu sunulmuş bir sorumluluktur ve dolayısıyla da bu sorumluluğun yerine getirilmiş olduğuna ilişkin, diğer bir deyişle geribildirim niteliğinde bir hesap verme gerektirir. Aynı zamanda da bu sorumluluğun yerine getirildiğinin de gözlemlenmesi gerekir.

(2) Çoklu amaçlar/hedefler: Pek çok kamu işletmesinin amacı kar elde etmek değil, hizmet sunmak, kaynak tahsis edilmesini sağlamak ve/veya politika geliştirmektir. 
(3) Haklar ve yükümlülükler: Hükümetlerin sahip oldukları haklar ve yükümlülükler onlara dolaylı ya da doğrudan içinde faaliyet gösterdikleri ekonomiyi ve toplumu etkileme gücü tanımaktadır. Sahip olunan hak ve yükümlülükler hükümet kademelerine göre farklılaşmakla birlikte vergilendirme ve mali politikayı belirleme, cezalandırma, para politikasını belirleme ve kanun ve düzenleme getirme ve uygulama imkanı tanımaktadır.

(4) Sahiplik yapısı olmaması: Kamu kuruluşları sahiplerine ekonomik fayda yaratacak olan koşulları iyileştirmek için faaliyette bulunmazlar.

(5) Yasal mevzuat tarafından belirlenmiş faaliyet ve finansal çerçeve: Kamu sektörü kuruluşları yasalarla düzenlenmiş bir çerçevede faaliyetlerini sürdürmek zorundadırlar.

(6) Bütçelerin önemi ve kullanılması: Bütçeler, hükümetlerin gelecek döneme ilişkin finansal planlarının aynasıdır. Finansal yönetim ve kontrol açısından anahtar niteliğindedir.

(7) Yönetimin yapısı: Kamu kuruluşlarında yönetsel yapı yasama organı tarafından belirlenir ve seçilmiş devlet görevlileri tarafindan yürütülür.

(8) Kaynakların yapısı: Kamu kuruluşları açısından kaynaklar, gelecekte nakit akışları yaratmaktan ziyade hizmet sağlaması amacıyla elde tutulmaktadır. Örneğin, miras ve kültürel kaynaklar, karmaşık altyapı ve savunma sistemleri bu kapsamdadır.

(9) Bedel karşıllğı olmayan işlemler/faaliyetler: Hükümetlerin elinde bulundurduğu vergilendirme, cezalandırma, kanun koyma gibi hak ve sorumluluklar ortaya bedel karşılığ1 olmayan faaliyetlerin çıkmasına neden olacaktır. Bir kamu işletmesinin işlemlerinin/faaliyetlerinin büyük bir kısmı bedel karşılığı olmayanlardan oluşmaktadır.

$\mathrm{Bu}$ çerçevede, IPSAS'ları uygulayanlar, kavramsal çerçeve uyarınca kamu sektörü ulusal, alt-ulusal (bölgesel, eyalet/il ve yerel), devlet ve devletle ilişkili diğer kamu kuruluşları ve uluslararası kamu sektörü kuruluşlarından (OECD, NATO vb.) oluşmaktadır (önsöz, paragraf 1). Kamu iktisadi teşekkülleri bu kapsamda değildir (Yanık ve Öztürk, 2018).

\subsection{Uluslararası Kamu Sektörü Muhasebe Standartları’nın Benimsenmesinin Faydaları}

Merkezi İngiltere'de bulunan Yeminli Mali Müşavirler Birliği (The Association of Chartered Certified Accountants (ACCA) 2017 yılında IPSAS'ların küresel olarak uygulanmasına ilişkin yaptığ çalışmasında söz konusu standartların benimsenmesine ilişkin olarak tespit ettiği faydaları aşağıdaki biçimde raporlamıştır:

(1) Daha yüksek düzeyde hesap verebilirlik ve şeffaflık: IPSAS, kamu sektörü finansal tablolarının düzenlenmesinde hesap verebilirlik ve şeffaflık kavramlarını oldukça ön planda işleyerek hile ve hatanın belirlenmesine engel teşkil eden hususlara karşı önlem almıştır. IPSAS ile uyumlu olarak düzenlenen finansal tablolar hükümetin/devletin (government) ne alıp ne paylaştırdığı ve aynı zamanda da nelere sahip ve nerelere borçlu olduğunu tam olarak yansitacaktır.

(2) Daha iyi karar vermeye imkan tanıması: Bir kuruluşun finansal durumu hakkında yeterince açık, anlaşılır ve güvenilir bilgilere sahip olmak karar vericiler açısından, kuruluş ve 
kuruluşun faaliyetlerine ilişkin finansal yargılara ulaşmalarında daha gerçekçi ve net olmalarını sağlayacaktır.

(3) Artırılmış etkinlik: IPSAS'ın benimsenmesi finansal raporlama ve denetim süreçlerinin daha etkin ve etkili biçimde gerçekleştirilmesini sağlamaktadır. IPSAS'ın kullanılması finansal ve kritik önemi sahip finansal olmayan bilgilerin entegrasyonunu artırmak için önemli bir araçtır. Bu sayede devlet kuruluşunun gerçek performansı hakkında daha bütüncül bir bakış açısı sağlanabilir. IPSAS'ın devlet kuruluşlarına sunduğu standart raporlama ve konsolidasyon imkanı sayesinde ortaya çok daha anlamlı bir denetim raporu çıkar. Daha anlamlı bir denetim raporu da karar verme sürecinde önemli bir rol oynar.

(4) Verilerin tutarlılığı: Raporlama sürecinin standartlar ile destekleniyor olması ve bu sayede sağlanmış olan temel bilgiler, verilerin analiz edilmesi ve karar verme sürecinin geliştirilmesine yönelik firsat yaratmaktadır.

(5) Güvenilir, sağlam finansal yönetim: IPSAS'ın benimsenmesi, devlet kuruluşlarına, yerel uygulamaları benimseyerek sağlayamayacağı bir takım finansal yönetim uygulaması avantajları sağlamaktadır. IPSAS'ın uygulanması aynı zamanda kuruluşun daha güçlü bir finansal yeterliliğe dolayısıyla da daha yüksek bir “değere” sahip olduğuna ilişkin gösterge niteliğindedir.

(6) Profesyonelleşme ve yeteneğin değerlendirilmesi: IPSAS'ın benimsenmesi bir kuruluşun muhasebe-finansman fonksiyonuna ilişkin olarak yürütülen işlerin profesyonelce yürütüldüğüne dair önemli bir göstergedir. Bu durum genç yetenekleri işlerin profesyonelce yürütüldüğü kurumlarda çalışmaya ya da bu tür kuruluşların muhasebe denetimi faaliyetlerini yürüten bir ekibin parçası olmaya özendirmek ve teşvik etmek açılarından açısından önemlidir.

(7) Daha geniş ekonomik ve sosyal imkanlara sahip olmak: IPSAS'ın belirttiği standartlar ile uyumlu olarak düzenlenmiş olan mali tablolar, uluslararası yatırımcılara güven sağlar. Uluslararası yatırımcılara sağlanan güven ise daha geniş bir ekonomik perspektiften iş imkanları, refah seviyesi ve toplumsal gelişim açılarından olumlu sonuçlar doğuracaktır.

(8) Hükümetin istikrarı: IPSAS'1n benimsenmesi sayesinde oluşacak güven ortamı hükümetin daha istikrarlı olmasına neden olabilir. Hükümetin daha istikrarlı olması ile dolaylı olarak daha iyi bir yatırım ortamı, daha çok iş imkanı ve daha yüksek gelir sağlanabilir.

(9) Uluslararası karşılaştırılabilirlik: Ortak dil olarak IPSAS'1 kullanmak, devlet kuruluşlarının uluslararası platformda birbiri ile karşılaştırılabilmesine imkan tanımaktadır. Aynı zamanda, Dünya Bankası ve IMF gibi bağışçı kuruluşların istediği ek finansal raporları düzenleme yükümlülüğü de azalmaktadır.

\section{Dünyada Görülen Kamu Sektörü Muhasebe Standartları Uygulamaları}

\subsection{Avrupa Birliği’nde Kamu Sektörü Muhasebe Standartları Uygulamaları}

Avrupa Birliği (AB), temeli IPSAS’lara dayanan,Avrupa Kamu Sektörü Muhasebe Standartları'nı (European Public Sector Accounting Standards - EPSAS) 2015 yılında 
yayınlamış ancak Avrupa Birliği ülkelerinin EPSAS ile uyumlu mali tabloları hangi tarih itibari ile düzenlemesi gerektiğine ilişkin bir belirleme yapmamıştır. EPSAS'ın altında yatan temel güdü, $A B$ ülkelerinin kamu sektöründe tekdüze, karşılaştırılabilir ve tahakkuk esaslı mali tablolar düzenlenmesini sağlamaktır. Tekdüze mali tabloların öncelikle devlet muhasebesi açısından dünyada yaşanan gelişmelerden kabul edilen ve AB üyesi ülkelerde bütçe kararlarının ekonomik sürdürülebilirliğine odaklanan Avrupa Hesap Sistemi’nde (European System of Account - ESA95) raporlanan verilere dayanak teşkil eden bilgilerin kalitesini artırması ve dolayısıyla, makro düzeyde bütçe gözetimine ve mali izlemeye imkan sağlaması söz konusudur (ACCA, 2017). Karşılaştırılabilir mali tabloların, mali istikrarın ve $\mathrm{AB}$ ülkeleri arasında daha derin bir ekonomik ve finansal entegrasyonun sağlanmasına yardımcı olması beklenmektedir.

\subsection{Avrupa Birliği Ülkelerinde Kamu Sektörü Muhasebe Standartları Uygulamaları}

Statistical Office of the European Communities (EUROSTAT) ${ }^{\mathrm{a}}$ tarafindan periyodik olarak yayınlamakta olan EDP Notification Tables ${ }^{b}$ istatistikleri incelendiğinde, 2018 yılı kasım ayı verilenine göre Avrupa ülkeleri genelinde merkez hükümet düzeyinde nakit esaslı muhasebe uygulamalarının yerel hükümet düzeyinde ise tahakkuk esaslı muhasebe uygulamalarının ağırlıklı olarak benimsendiği izlenmiştir (EUROSTAT, 2018). Estonya 2004 yılında IPSAS benzeri standartları uygulamaya başlamıştır. Litvanya'da IPSAS'a tam uyum 2014 yılında sağlanmış ve Letonya'da ise IPSAS uyum çalışmalarının 2019 yılında sona ermesi beklenmektedir (ACCA, 2017). Lüksemburg devlet muhasebesi uygulamalarında uyarlanmış nakit esaslı yöntemi tercih etmiştir. Ülkede 2014 yılında günümüze kadar tahakkuk esaslı yönteme geçilmesine ilişkin henüz resmi bir plan bulunmamaktadır.

$\mathrm{Bu}$ çerçevede, aşağıda $\mathrm{AB}$ ülkelerinde ve İsviçre'de kamu sektörü muhasebe standartlarına ilişkin gelişmeler ülke bazında incelenmiştir.

\subsubsection{Estonya}

Estonya Avrupa'da IPSAS'a uyum sağlayan ilk ülke ve aynı zamanda AB ülkeleri arasında tüm kamu sektörü seviyeleri için aynı düzeyde IPSAS uygulayan birkaç ülkeden bir tanesidir. (ACCA, 2017). Estonya 2004 yilından bu yana IPSAS ile uyumlu finansal raporlama yapmaktadır (Giuseppe ve diğerleri, 2018).

\subsection{2. İsveç}

İsveç merkez hükümeti 90’1ı yıllardan bu yana tüm merkez hükümet yürütme organlarını da kapsayacak biçimde tahakkuk esaslı muhasebe uygulamaktadır. İsveç Hükümeti, 29 Eylül 2011 günü İsveç Ulusal Finansal Otoritesini (ESV) İsveç Merkez Hükümeti Yıllık Raporları ile Konsolide Finansal Tablolarını hazırlamakta kullanılmakta olan muhasebe kural ve düzenlemelerinin uluslararası standartlarla karşılaştırılması gerekli görülen

\footnotetext{
a'Eurostat, Avrupa Birliği’nin Lüksemburg'da olan istatistik ofisidir. Temel görevi ülkeler ve bölgeler arasında karşılaştırma olanağı sağlayan Avrupa düzeyinde istatistiki veriler sunmaktır.

${ }^{\mathrm{b}} \mathrm{Bu}$ tablolar, ulusal bütçe toplamlarıyla ve borçtaki açık ile değişiklikler arasında bağlantıyı tutarlı bir çerçeve sağlamak için özel olarak tasarlanmıştır muhasebe veri ve bilgilerinden oluşan ve düzenli olarak yılda iki kez Eurostat tarafindan yayınlanan tablolardır.
} 
hususlar ile alakalı olarak Merkez Hükümet Muhasebe Kurallarında değişikliğe gidilmesi hususu çerçevesinde görevlendirmiştir (OECD, 2012).

Ülkede özel sektör işletmeleri IFRS’lere tabidir. Devlet muhasebesi için kullanılan muhasebe standartları ile özel sektör için kullanılmakta olan muhasebe standartları özel durumlar dişında birbiri ile paralel uygulamalar içermektedir. IPSAS düzenlemelerinin de IFRS temelli uygulamaları benimsediği göz önünde bulundurulduğunda, ülkede devlet muhasebesi için kullanılmakta olan düzenlemelerin de birebir olmasa dahi, IPSAS temelli olduğundan söz etmek olasıdır.

\subsubsection{Belçika}

Belçika, AB ülkeleri arasında İspanya, Almanya, Lüksemburg ve Yunanistan ile beraber en karmaşık muhasebe uygulamasına sahip ülkelerden bir tanesidir (ErnstandYoung, 2012). Söz konusu karmaşıklık, halihazırda uygulanan muhasebe yasalarının sayısının çok olmasına dayanmaktadır. Yasaların sayısının çok olması bazı hallerde uygulama ile yasal düzenlemeler arasında ihtilaf çıkmasına neden olmaktadır.

Bir diğer husus ise Belçika'nın çok sayıda millet ve bölgelerden oluşan federal bir devlet olmasıdır. Milletler ve bölgeler her ne kadar bütçeleme ve muhasebeleştirmeye ilişkin düzenlemeleri belirlemede özgür de olsalar tüm kurumlar tarafindan ortak olarak uygulanan ve yasalarca belirlenmiş olan kurallara da saygı göstermek zorundadırlar (Bellanca ve Vandernoot, 2013). Ülkede üç farklı dil aynı anda konuşulmaktadır.

Yukarıda değinilen koşullar ülkede IPSAS'ın benimsenmesi ve uygulanmasını güçleştirmektedir. Tüm bu olumsuzluklara rağmen ülkede 2003 yılında reform niteliğinde yeni bir muhasebe yasası yayınlanmıştır. Bu yasa ile beraber tüm federal devlet ve muhasebe uygulamaları bir hesap cetveli kullanılmak suretiyle tahakkuk esaslı uygulamaya dönüştürülmüştür. Yeni muhasebe yasası düzenlemeleri temel olarak IPSAS düzenlemeleri ile paralel görünse de Belçika'da IPSAS'ın tam olarak uygulandığından söz etmek olası değildir. Belçika'da yalnızca üç federal bölgesi olan Flaman yerel hükümeti IPSAS'a uyum sağlamış, Valonya'da ise yerel hükümet bazında tahakkuk esaslı muhasebe uygulanmakta ve merkez hükümet bazında ise tahakkuk esaslı muhasebe uygulamasına geçilmesi yönünde plan yapılmaktadır (Christiaens ve diğerleri, 2015:166).

\subsection{4. İsviçre}

İsviçre'nin IPSAS ile tam uyum içinde olmayışının en temel nedeni ülkedeki kamu sektörü yapısının oldukça karmaşık olmasıdır (Polzer ve diğerleri, 2017: 13). İsviçre Ulusal Finansal Yönetim Kurumu (The Swedish National Financial Management Authority (ESV)) IPSAS'ların bu ülkede uygulamasına yönelik kısıtlar öne sürmektedir(Polzer ve diğerleri, 2017: 13). Söz konusu kısıtlar (1) IPSAS'lara tam uyum için gerekli hazırlık ve çalışmaların oldukça büyük bir maliyet unsuru yaratacağı, (2) IPSAS'lara uyumun uzun zamanı kapsayacağı, (3) IPSAS'da yer alan tavsiyelerin tam olarak İsviçre yönetiminin beklentilerini karşılamadığı ve buna karşılık (4) IPSAS'ın gerektirdiği ayrıntılı sunum şartlarının da yönetimin beklentilerinin üzerinde ayrıntı içerdiği şeklindedir. 
IPSASB (2014a) çalışmasında, Federal hükümetin finansal durumuna ilişkin daha kapsamlı bilginin ortaya konmasına ilişkin olarak parlamento ve kamunun artan baskısı sonucu İsviçre Federal Mali Yönetimi (Swiss Federal Finance Administration (FFA) 2001 yılında İsviçre Konfederasyonu'nun tümünü kapsayacak biçimde ve aynı zamanda 2007 yılında yayınlanması planlanan IPSAS'a da paralel olacak şekilde muhasebe sistemini revize etmek için çalışmalarına başlandığı ortaya konmuştur.

2002 yılında FFA, ön hazırlık niteliğinde bir çalışma yaparak Yeni Muhasebe Modeli (New Accounting Model (NAM)) adında yeni bir muhasebe yöntemi ortaya koyarak, bütçeleme ve muhasebe uygulamaları açısından tamamen tahakkuk esaslı bir yöntem uygulanmasını öngörmüştür. 2003 yılının sonlarına doğru kavramsal bazdaprototip bir çalışma hazırlanmıştır. 2004 yılında ise tüm federal yönetim basamaklarını da kapsayacak nitelikte ve aynı zamanda da IPSAS ile uyumlu uygulamalar içeren yeni bir muhasebe sistemi geliştirme çalışmaları hız kazanmıştır. 2007 yılında ilk kez NAM uyumlu finansal tablolar hazırlanarak 2008 yılı Mart ayında yayınlanmış ve ayın yılın Haziran ayında da parlamentoda kabul edilmiştir. Ülkede 2007 yılından bu yana bütçeleme ve muhasebe uygulamaları tahakkuk esaslı olarak sürdürülmektedir. FFA halen mevcut sistemin niteliğinin artması ve mevcut uygulamanın IPSAS ile en yakın hale gelmesinin sağlanması için çalışmalarını sürdürmektedir.

\subsubsection{Lüksemburg}

Lüksemburg, kamu sektörü muhasebe uygulamalarında tahakkuk ve nakit esaslı yöntemleri karışık olarak kullanmaktadır. 2014 yılından bu yana bu ülkenin uyguladığı finansal yönetim ve muhasebe politikalarında yalnızca tahakkuk esaslı yöntemin benimsenmesine ya da yakın bir gelecekte benimseneceğine ilişkin resmi bir girişim de bulunmamaktadır. Bunun nedeni ise Lüksemburg'un kamu sektörü için gereken fonları oldukça rahat bir şekilde temin edebilmesi ve hükümetin borç düzeyinin düşük olması nedeniyle IPSAS ya da EPSAS benzeri standartlara uyulmasının acil seviyede önem atfedilen bir husus olmaması ve halihazırda kullanılan muhasebe düzenlemelerinin hükümetin bu konudaki ihtiyacını tam olarak karşılıyor olmasıdır (Ernstand Young, 2017).

\subsubsection{Bulgaristan}

Bulgaristan’da merkezi hükümet ve merkezi hükümete bağlı olarak faaliyet gösteren kamu kuruluşları, örneğin üniversiteler, bilim akademileri ve bakanlıklar ve yerel hükümet ulusal muhasebe mevzuatına bağlı olarak finansal tablo ve bütçe düzenlemektedirler. Merkezi ve yerel hükümetin tabi olduğu muhasebe mevzuatı kamu sektörü raporlaması açısından $\mathrm{AB}$ düzenlemelerine, muhasebe kural, kavram ve genel çerçevesinin belirlenmesi açısından IMF ve IPSAS düzenlemelerine ilişkin hükümleri kapsamakla birlikte bütçe düzenlemekle yükümlü olan tüm raporlayan kamu kuruluşlarının fonlarının ve harcamalarının yönetilmesi ve denetlenmesine ilişkin faaliyetlerde ise Bulgaristan mevzuatına ilişkin kural ve düzenlemeleri içermektedir (Ernstand Young, 2012).Kamu hastanelerine, ulusal yollara, yerel yönetimlere ve kamuya ilişkin fonlar IFRS'ye veya Bulgaristan Küçük ve Orta Büyüklükteki İşletmeler Finansal Raporlama Standartları düzenlemelerine tabidir (Ernstand Young, 2017).

Bulgaristan'ın IPSAS ile uyumlu finansal tablolar düzenleyebilmesi için öncelikle mevcut yerel uygulamaların IPSAS ile uyumlu hale getirilmesi gerekmektedir. Halihazırda 
ülkede IPSAS'ın Bulgar dilinde resmi olarak tercümesi bulunmamaktadır(Feschiyan, 2010: 1557).

\subsubsection{Romanya}

Romanya'da kamu sektöründeki muhasebe reformu 2002 y1lında hükümetin nakit esaslı muhasebe uygulamalarının yanısıra tahakkuk esaslı uygulamaları da kullanmaya karar vermesi ile başlamıştır. 2005 yılında seçilen bazı kuruluşlar pilot uygulama kapsamında tahakkuk esaslı muhasebe uygulamasına geçmiş, tüm kamu kurumlarında ise tahakkuk esaslı uygulamanın benimsenmesi 1 Ocak 2006 tarihinde gerçekleşmiştir. IPSAS'ın ilk Romen versiyonu2009 yılında yayınlanmış ve bu süreç 2013 yılında kadar revize edilmek suretiyle de devam etmiştir (Besteliu, 2018). Ülkede halen IPSAS’a tam uyumdan söz edilememektedir.

\subsection{8. İspanya}

İspanya'da kamu sektörü ulusal devlet, bölgesel yönetimler ve yerel yönetimler olmak üzere üç kademeli olarak organize edilmiştir. Her üç kademedeki bütçeleme, muhasebe ve denetim uygulamaları birbiri ile benzerlik göstermektedir. Kamu sektörüne ilişkin muhasebe standartlarının IPSAS ile tam uyum sağlamasına yönelik çalışmalara 2010 yılında başlanmıştır. 2011 yılından bu yana merkezi hükümet, 2015 yılından bu yana ise yerel yönetimlerde IPSAS ile uyumlu yerel standartlar uygulamakta, bölgesel yönetimlerde ise yakın bir zamanda IPSAS ile uyumlu yerel standartların benimsemesine ilişkin çalışmalar devam etmektedir (Jorge, 2015).

\subsubsection{Almanya}

Almanya' da tahakkuk bazlı muhasebe ve EPSAS'a uyum sağlanmasına yönelik olarak federal devlet düzeyinde herhangi bir çalışma bulunmamaktadır. 2014 yılında yapılan en son görüşme ile Bavaria eyaleti tahakkuk bazlı muhasebe ve EPSAS'ın uygulanmasını reddetmiştir. Buna karşılık Hamburg eyaleti halen tahakkuk bazlı muhasebe ve EPSAS'1 uygulamaktadır. Almanya'nın en büyük eyaleti olan North Rhine-Westpalia, tahakkuk bazlı muhasebe uygulamalarını benimsemek için aktif olarak çalışmaktadır.

\subsubsection{Malta}

Malta, 2019 yılında IPSAS'a tam uyum vaat etmiştir. Bu ülkede, halihazırda nakit esaslı uygulanan fakat tahakkuk bazlı sunulan, uyarlanmış tahakkuk esaslı (modified accrual) muhasebe uygulamaktadır.

IPSASB (2014b) çalışmasında, Malta'nın tahakkuk esaslı muhasebe uygulamasına geçişinin 1999 yılında Finans Bakanlığı'nın kamu kesiminin tahakkuk esaslı muhasebe uygulamalarına ilişkin yayınlamış olduğu genelge ile başladığı ortaya konmuştur. Bu genelgenin amacı kamu kesimi mali tablolarının finansal öngörülere ve planlamaya altyapı sağlayacak düzeyde anlamlı finansal bilgiler içermesine yönelik beklentidir. 2012 yılında Avrupa Birliği, üye ülkelerin uluslararası kamu sektörü muhasebe standartlarına uyumlu olacak biçimde muhasebe uygulamalarının şekillendirilmesine yönelik beklentisinden söz edince dönemin yeni Finans Bakanı 2013 yılında tahakkuk esaslı muhasebe uygulamasının benimsenmesine ilişkin çalışmalara hız kazandırmıştır. Aynı yılda ülkede tahakkuk esaslı 
muhasebe uygulamasının faydalarının ortaya konmasına yönelik çalıştaylar düzenlenmiştir. 2016 yılında Finans Bakanlığı, 2018 yılında ise seçilen pilot departmanlar ve bakanlıklar tahakkuk esaslı muhasebe bilgileri üretmeye ve kullanmaya başlamışlardır. 2019 yılında pilot uygulama yapanlar dişında kalan diğer tüm departman ve bakanlıkların tahakkuk esaslı muhasebe uygulamasını benimsemesi beklenmektedir.

\subsubsection{1. Çekya (Çek Cumhuriyeti)}

Çekya, 1 Ocak 2010 tarihinden bu yana, kamu sektörü için yeni ulusal muhasebe standartları yayınlamak suretiyle tahakkuk esaslı uygulamaya geçiş yapmış ve kamu sektörüne ait ilk tahakkuk esaslı finansal tablolarını da 2010 yılında yayınlamıştır (Otrusineva ve diğeri, 2013). Çekya Yüce Denetim Ofisi (SAO) 2016 yılında IPSAS'ın birebir çevirisi niteliğinde olan IPSAS rehberini hazırlamış ve uygulamaya sunmuştur (Czech Republic Supreme Audit Office, 2018).

\subsubsection{Yunanistan}

Yunanistan, uluslararası standartları uygulama ve uyum açısından Avrupa'daki en ilginç ülkedir. Temel olarak devlet bazında uyarlanmış nakit esaslı muhasebe standartları uygulanmakta olması tahakkuk esaslı uygulamaların benimsenebileceğine ilişkin bir gösterge sayılabilir. Bu ülkedeki hastanelerde, belediyelerde ve birkaç hükümet kurumunda tahakkuk esaslı muhasebe uygulanmaktadır. Buna karşılık, kamu sektörüne ilişkin bütçe nakit bazlı muhasebe uygulamalarına dayanılarak hazırlanmakta ve bütçenin sunumu ise yine kendine özgü bir biçimde kalem bazında gerçekleştirilmektedir. Yunanistan'da 2014 yılında EPSAS ve tahakkuk esaslı muhasebe uygulamalarının benimsenmesine yönelik bir çalışma komitesi kurulmuş olmasına rağmen o zamandan beri bu konuda bir ilerleme ve gelişme kaydedilememiştir.

\subsubsection{Hollanda}

Hollanda'da merkezi hükümet ve yürütme organları bazı istisnaları bulunmak üzere, nakit esaslı muhasebe uygulamaktadırlar. Bunun yanı sıra yerel hükümet uyarlanmış tahakkuk esaslı muhasebe uygulamaktadır. Bu ülkede merkezi hükümetin halihazırda kullandığ yöntemi değiştirmek için resmi bir planı bulunmamasına rağmen kullanılan nakit esaslı yönteme bazı tahakkuk esaslı unsurlar eklenmesi yönünde çalışmalarda bulunmaktadır.

\subsubsection{Avusturya}

Avusturya, yasal geleneklerine bağlı olarak ülkede kamuya ilişkin bütçeleme ve muhasebe standartları yasalara, yönetmeliklere ve yönergelere dayanmaktadır. Dolayısıyla da ülkede bütçeye ve muhasebeye ilişkin reformlar için çoğunlukla yasa değişikliğine gidilmesi zorunludur.

$\mathrm{Bu}$ ülke federal devlet bazında, tahakkuk esaslı muhasebe uygulamaları ve bütçeleme ile 2007-2009 yılları arasında tanışmıştır (Polzer ve diğerleri, 2016). Ülkede halen federal devlet ve alt ulusal kademeler arasında bütçeleme ve muhasebe uygulamaları açısından çoğulluk ve karmaşıklık hüküm sürmektedir. 
Diğer taraftan, 2014 y1lında görüşülmeye başlanan yeni bütçe ve raporlama yönetmeliğinin 2018 yılı itibarıyla uygulamaya konması beklenmektedir. Bu yönetmeliğin uygulamaya konmasiyla beraber ülkede federal devlet ve alt ulusal devlet kademeleri arasındaki muhasebe ve bütçe uygulamalarının uyumlaştırılması ve tahakkuk esaslı uygulamaların benimsenmesi ile beraber IPSAS'a yakınlaşma beklenmektedir. Dolayısıyla IPSAS'a tam uyum söz konusu olmamakla birlikte kısmi uyumdan söz etmek mümkündür. Bazı standartlara uygulama alanı bulunamadığı için, örneğin IPSAS 10 Yüksek Enflasyonlu Ekonomilerde Raporlama gibi, bazı standartlara da Avusturya'nın kendisine özgü yerel muhasebe uygulamalarına yer verilmesi amacıyla adaptasyon sağlanamamıştır (Polzer ve diğerleri, 2017: 13).

\subsubsection{Fransa}

Fransa, devlet kuruluşlarında uygulanacak olan, bütçe hariç, tahakkuk esaslı yönteme (The LOLF) 2004 yılında uyum sağlamıştır. Fakat,ülke genelinde IPSAS'ın benimsenmesi yerine Kamu Hesapları Konseyi (The Conseil de Normalizationdes Comptes Publics (CNOCP)) tarafından oluşturulmuş olan yerel muhasebe standartlarının uygulamaya konması tercih edilmiştir. Her ne kadar Fransız hükümeti IPSAS'ın uygulanabilirliği ve kullanılabilirliği konularında eleştirel bir yaklaşım sergilese de aslında CNOCP standartları açıkça belirtilmese de IPSAS'ın kavram ve kurallarını üstü kapalı olarak işaret etmektedir (Polzer ve diğerleri, 2017: 13).

\subsubsection{6. İtalya}

İtalya'da yerel yönetimlerde nakit ve tahakkuk esaslı yöntemleri biraya getiren, uyarlanmış nakit esası benzeri bir muhasebe yöntemi kullanılmaktadır. Bununla birlikte, bütçeye ilişkin muhasebe bilgileri ise tahakkuk esaslı veriler aracılığıyla sağlanmaktadır. 2014 yılından bu yana merkez ve yerel yönetimler bazında tahakkuk esaslı muhasebe uygulamasının benimsenmesine yönelik bir adım atılmamıştır (Polzer ve diğerleri, 2017)

\subsubsection{7. İngiltere}

İngiltere'de kamu sektörü muhasebe uygulamalarına yön veren kuruluş Hazine'dir. Hazine, kamu sektörü muhasebe uygulamalarında temel olarak IFRS'den uyarlanmış standartlar ve beraberinde Hazine'nin bu konuya ilişkin yapacağı yorum ve açıklamaların birlikte kullanılmasını öngörmektedir. Bu kapsamda İngiltere kamu sektörü muhasebesi uygulamalarında IFRS düzenlemelerine dayanan tahakkuk esaslı bir yöntem kullanmaktadır (Fisher, 2018). Diğer taraftan, İngiltere, üyelikten çıkarak AB ülkesi olma özelliğini yitirmek üzeredir. Dolayısıyla, AB'den çıktığı andan itibaren IPSAS/EPSAS düzenlemelerine uyum sağlanmasına ilişkin tavsiye ve yaptırımları da göz ardı etmesi beklenen bir sonuç olacaktır.

\subsubsection{Portekiz}

Portekiz, merkez ve yerel yönetimlerden oluşan üniter bir devlettir. Ülkede bütçelemeye ilişkin faaliyetlerin raporlanmasında nakit esaslı diğer muhasebe uygulamalarında ise (örneğin varlık ve yükümlülüklerin muhasebeleştirilmesinde) tahakkuk esaslı yöntem kullanılmaktadır. 90'lı yıllardan bu yana kamu sektörüne ilişkin muhasebe standartları kullanılmaktadır. Fakat kullanılan standartlar kar amacı gütmeyen kamu 
kuruluşları ve merkez ve yerel yönetimler açısından benzer konularda farklı uygulamalar sunmaktadır. Ülkede 2013 yılında IPSAS/EPSAS düzenlemeleri ile uyumlu standartların benimsenmesi yolunda bir çalışma başlatılmıştır (Jorge, 2015). Çalışmalar halen devam etmektedir.

Gerek AB ülkeleri ve gerekse birlik dışında kalan Avrupa ülkelerine ilişkin olarak devlet muhasebesi uygulamalarında kullanılan muhasebe yöntemleri aşağıda Tablo 2'de gösterilmiştir.

Tablo 2 .Avrupa Ülkelerinde Merkez, Eyalet, Yerel Hükümet ve Sosyal Güvenlik Fonları Düzeyinde Uygulanan Muhasebe Yöntemleri

\begin{tabular}{|c|c|c|c|c|}
\hline Ülkeler & $\begin{array}{c}\text { Merkez } \\
\text { Hükümet }\end{array}$ & Eyalet & $\begin{array}{c}\text { Yerel } \\
\text { Hükümet }\end{array}$ & $\begin{array}{c}\text { Sosyal Güvenlik } \\
\text { Fonları }\end{array}$ \\
\hline Karısık & Karışık & Karışık & Karışık & Karışık \\
\hline Avusturya & Nakit & Karışık & Karışık & Tahakkuk \\
\hline Belçika & Karışık & Karışık & Tahakkuk & Tahakkuk \\
\hline Bulgaristan & Nakit & - & Nakit & Nakit \\
\hline Çek Cumhuriyeti & Nakit & - & Nakit & Tahakkuk \\
\hline Danimarka & Karışık & - & Karışık & Karıș1k \\
\hline Estonya & Tahakkuk & - & Karışık & Tahakkuk \\
\hline Finlandiya & Karışık & - & Karışık & Tahakkuk \\
\hline Fransa & Nakit & - & Tahakkuk & Tahakkuk \\
\hline Hirvatistan & Nakit & - & Karış1k & Karışık \\
\hline Hollanda & Nakit & - & Tahakkuk & Tahakkuk \\
\hline İngiltere & Nakit & - & Nakit & - \\
\hline İrlanda & Nakit & - & Tahakkuk & - \\
\hline İspanya & Tahakkuk & Tahakkuk & Tahakkuk & Tahakkuk \\
\hline İsveç & Nakit & - & Tahakkuk & Karış1k \\
\hline İsviçre & Nakit & - & Tahakkuk & Karışık \\
\hline İtalya & Nakit & Nakit & Nakit & Nakit \\
\hline Letonya & Nakit & - & Nakit & Nakit \\
\hline Litvanya & Nakit & - & Nakit & Tahakkuk \\
\hline Lüksemburg & Karışık & - & Karışık & Tahakkuk \\
\hline Macaristan & Nakit & - & Nakit & Nakit \\
\hline Malta & Nakit & - & Tahakkuk & - \\
\hline Polonya & Nakit & - & Nakit & Tahakkuk \\
\hline Portekiz & Nakit & - & Nakit & Nakit \\
\hline Romanya & Nakit & Nakit & Nakit & Nakit \\
\hline Slovenya & Nakit & - & Nakit & Nakit \\
\hline Yunanistan & Nakit & - & Nakit & Karışık \\
\hline
\end{tabular}

Kaynak: Tablo yazarlar tarafindan Eurostat EDP Notification Table, 2018 yll Kasim ayl verileri kullanılarak derlenmiştir. 


\subsection{Avrupa Dışında Kalan Dünya Ülkeleri Kamu Sektörü Muhasebe Standartları Uygulamaları}

AB'nin 2015 y1lında EPSAS'ları yayınlaması ve üye ülkelerin bu standartlara uyum tarihlerine ilişkin açıklanmalarından sonra AB ülkeleri dışında kalan ülkelerde de IPSAS'lara olan uyum sürecinin hızlandığından söz etmek olasıdır. Avustralya ve Yeni Zelanda halihazırda kamu sektörü uygulamaları açısından IFRS'den IPSAS benzeri standartlara geçiş yapmışlar, Afrika, Güney Doğu Asya ve Güney Amerika ülkeleri ise gelişmekte olan ülkeler olarak IPSAS ile uyum süreci eğilimine girmiş bulunmaktadırlar (ACCA, 2017). Genel durum, Tablo 3'de sunulmuştur.

\section{Tablo 3. Dünya Ülkeleri Genelindeki Mevcut IPSAS Uygulamaları}

\begin{tabular}{|c|c|c|c|}
\hline Ülkeler & Merkez Hükümet & Eyalet & Yerel Hükümet \\
\hline Abu Dabi & Devam ediyor & $\begin{array}{l}\text { Tahakkuk esaslı muhasebe uygulamayı taahhüt } \\
\text { etmiştir, halihazırda nakit esaslı muhasebe } \\
\text { uygulamaktadır. }\end{array}$ & $\begin{array}{l}\text { Henüz } \\
\text { açıklanmamıştır }\end{array}$ \\
\hline Bangladeş & Devam ediyor & $\begin{array}{l}\text { IPSAS standartlarını nakit esaslı olarak } \\
\text { uygulamaktadır. }\end{array}$ & $\begin{array}{l}\text { Henüz } \\
\text { açıklanmamıştır. }\end{array}$ \\
\hline Endonezya & Uyum sağladı & $\begin{array}{l}\text { IPSAS tipi standartlar uygulamaya başlamıştır, } \\
\text { fakat merkez ve yerel yönetimlere ilişkin uygulama } \\
\text { halihazırda nakit ve tahakkuk esaslarının karışımı } \\
\text { bir uygulamadır. }\end{array}$ & 2015 \\
\hline Nepal & Kismi Uyum & $\begin{array}{l}16 \text { Bakanlık için nakit esaslı standartlar } \\
\text { uygulanmaktadır. Tahakkuk esaslı standartlara } \\
\text { geçilmesi yönünde bir bildirim bulunmamaktadır. }\end{array}$ & $\begin{array}{l}\text { Henüz } \\
\text { açıklanmamıştır. }\end{array}$ \\
\hline Pakistan & Devam ediyor & $\begin{array}{l}\text { Merkez hükümet için nakit esaslı IPSAS } \\
\text { uygulanmaktadır. }\end{array}$ & $\begin{array}{c}\text { Henüz } \\
\text { açıklanmamıştır. }\end{array}$ \\
\hline Sri Lanka & Devam ediyor & $\begin{array}{l}10 \text { adet IPSAS standardı uygulamaya konmuştur. } \\
2006 \text { y1lında } 2012 \text { yılına değin } 21 \text { IPSAS } \\
\text { standardının uygulamaya konulacağı duyurulmuş, } \\
\text { fakat gerçekleşmemiştir. }\end{array}$ & $\begin{array}{l}\text { 2012, henüz } \\
\text { tamamlanmamıştır. }\end{array}$ \\
\hline Nijerya & Kismı Uyum & $\begin{array}{l}2016 \text { yılında IPSAS uygulanmaya başlanmıştır. } 36 \\
\text { bağımsız eyalet kendine ilişkin uygulama takvimini } \\
\text { uygulayacaktır. }\end{array}$ & 2016 \\
\hline
\end{tabular}




\begin{tabular}{|c|c|c|c|}
\hline Güney Afrika & Kism1 Uyum & $\begin{array}{l}\text { Yerel hükümet (localgovernment) } 2009 \text { y1lında } \\
\text { GenerallyRecognised Accounting Practice (Genel } \\
\text { Kabul Görmüş Muhasebe Uygulaması, GRAP) } \\
\text { standartlarını uygulamaktadır. Uluslararası ve iller } \\
\text { bazındaki kamu kuruluşlarında (national and } \\
\text { provincial publicentities) bazı hallerde IFRS, bazı } \\
\text { hallerde ise GRAP uygulamalarını benimseyen } \\
\text { uyarlanmış nakit esaslı (modified cash) yöntem } \\
\text { kullanılmaktadır. }\end{array}$ & 2009 \\
\hline Tanzanya & Uyum sağladi & $\begin{array}{l}\text { Kamu kuruluşlarının tüm kademelerinde tahakkuk } \\
\text { esaslı IPSAS uygulanmaktadır. }\end{array}$ & 2013 \\
\hline Zambiya & Devam ediyor & $\begin{array}{l}2016 \text { yılında nakit esaslı IPSAS uygulamaya } \\
\text { başlamış ve } 2020 \text { y1lında tahakkuk esaslı IPSAS'a } \\
\text { geçmeyi taahhüt etmiştir. }\end{array}$ & $\begin{array}{c}2016 \text { başlangıç }-2020 \\
\text { bitiş }\end{array}$ \\
\hline Zimbabwe & Planmıştır & $\begin{array}{l}\text { Merkez hükümet ve yerel otoriteler halen nakit } \\
\text { esaslı yöntemler uygulamaktadır. } 2021 \text { y1lında } \\
\text { tahakkuk esaslı IPSAS uygulamasının } \\
\text { benimsenmesi taahhüt edilmiştir. }\end{array}$ & 2021 \\
\hline Arjantin & - & $\begin{array}{l}\text { IPSAS ile uyumlu olmayan standartlar } \\
\text { kullanılmaktadır. }\end{array}$ & - \\
\hline Brezilya & Devam ediyor & $\begin{array}{l}\text { Halihazırda uyarlanmış tahakkuk esaslı (modified } \\
\text { accrual) standartlar kullanılmaktadır. IPSAS ile tam } \\
\text { uyumun } 2020 \text { yılında tamamlanmas } \\
\text { öngörülmüştür. }\end{array}$ & 2020 \\
\hline Şili & Devam ediyor & $\begin{array}{l}\text { Halihazırda uyarlanmış tahakkuk esaslı (modified } \\
\text { accrual) standartlar kullanılmaktadır. IPSAS ile tam } \\
\text { uyumun } 2019 \text { yılında tamamlanmas } \\
\text { öngörülmüştür. }\end{array}$ & 2019 \\
\hline Kolombiya & Devam ediyor & $\begin{array}{l}2007 \text { yılından itibaren kamu kuruluşlarında } \\
\text { tahakkuk esaslı uygulama kullanılmaya } \\
\text { başlanmıştır. } 2017 \text { y1lı sonunda IPSAS ile tam } \\
\text { uyumlu hale gelecektir. }\end{array}$ & 2017 \\
\hline Peru & Tam uyum & $\begin{array}{l}\text { IPSAS'a uyum süreci } 2006 \text { yılında başlamış ve } \\
2016 \text { y1lında tamamlanmıştır. }\end{array}$ & \\
\hline Barbados & Tam uyum & 2010 yılında tam uyum sağlanmıştır. & 2010 \\
\hline Guatemala & Devam ediyor & $\begin{array}{l}\text { Kamu hesaplarında tahakkuk esaslı uygulama } 1997 \\
\text { yılında başlamıştır. } 2005 \text { yılından bu yana da } \\
\text { IPSAS'a uyum çalışmaları sürmektedir. }\end{array}$ & 2005 başlangıç- \\
\hline Jameika & Devam ediyor & $\begin{array}{l}\text { Merkez hükümet uyarlanmış nakit esaslı standartlar } \\
\text { kullanmaktadır. }\end{array}$ & 2021 \\
\hline Meksika & - & $\begin{array}{l}\text { Kamu sektörü uyarlanmış tahakkuk esaslı } \\
\text { (modified accrual) standartlar kullanmaktadır, } \\
\text { IPSAS'a geçiş için herhangi bir plan } \\
\text { bulunmamaktadır. }\end{array}$ & - \\
\hline
\end{tabular}

Kaynak:The Association of Chartered Certified Accountants (ACCA) (2017) IPSAS implementation: Current Status and Challenges

Ayrıca, Türkiye'de 2005 yılından itibaren hızlanan kamu maliyesi mali ve idari reform çalışmaları sonucunda 5018 Sayılı Kamu Mali Yönetimi ve Kontrol Kanununun yayınlanıp yürürlüğe girmesiyle Türk devlet muhasebe sisteminde tahakkuk esasına geçilmiştir (Arslan, 2011). Bu doğrultuda, Haziran 2018 itibariyle temelini IPSAS'lardan alan 30 adet Devlet Muhasebesi Standardı (DMS) oluşturulmuştur. Ancak, bu standartların bazıları IPSAS'lara uyumlu bazıları ise DMS 1 Finansal Tabloların Sunumu standardında olduğu gibi temelini 
IPSAS'lardan alarak Türkiye'ye uyarlama niteliğindedir (Yanık \& Öztürk, 2018). IPSAS'larda yürürlükten kaldırılan IPSAS 6, IPSAS 7, IPSAS 8 standartları Türkiye'de henüz güncellenmemiştir (DMSK, 2018). Bu standartların IPSAS 34, IPSAS 35, IPSAS 36 ve IPSAS 37 olarak güncellenmesi Devlet Muhasebesi Standartları Kurulu'nun 2018 y1lından sonraki planları arasında yer almakta olup Kurulun hedefi bütün DMS’lerin IPSAS’larla tam uyumlu olması yönündedir. Kurul tarafından yapılan tespite göre 2015 yılında IPSAS'lara \%48 olan uyumun 2018 yılında \%89 olması hedeflenmiştir.

Diğer taraftan; IPSAS'ları benimsemeyen ancak IPSAS'lara benzer olarak tam tahakkuk esasına dayalı kendi standardını hazırlayan üç ülkeden de burada söz edilmesi küresel fotoğrafın oldukça tamamlanmasına yardımcı olacaktır.

Bu bağlamda, bu ülkelerden biri Amerika Birleşik Devletleri'dir. Bu ülkedeki Devlet Muhasebesi Standartları Kurulu (Governmental Accounting Standards Board - GASB) tarafindan hazırlanan Devlet Muhasebesi Standartları (Governmental Accounting Standards GAS) uygulanmaktadır. Kanada'da ise Kamu Sektörü Muhasebe Kurulu (Public Sector Accounting Board - PSAB) tarafindan Kamu Sektörü Muhasebe Standartları (Public Sector Accounting Standards - PSAS) yayınlanmakladır.

Son olarak Avustralya'da ise IFRS'ler son sürümleri üzerinden ele alınarak standartlara kar amacı gütmeyen kamu sektörü kuruluşlarına (not-for-profit public sectorentities) ilişkin IPSAS hükümleri eklenmiştir (AASB, 2018). Örneğin; IAS 23 Borçlanma Maliyetleri standardında eskiden yer alan temel yöntem ve alternatif yöntem yaklaşımları hali hazırda IPSAS 5 kapsamında devam ettiğinden Avustralya' da temel yöntem kamu sektörü kuruluşlarının uygulaması için AASB 123 (IAS 23)'e özel hüküm olarak eklenmiştir (AASB, 2015, 6). Ancak, bu noktada belirtmek gerekir ki Avustralya’da kamu sektöründeki raporlama da içine kar amacı gütmeyen kamu sektörü kuruluşlarına ilişkin IPSAS hükümleri eklenmiş IFRS ile yola devam etmek yerine kamu sektöründe doğrudan IPSAS’ların benimsenmesi Ağustos 2018'de Avustralya Muhasebe Standartları Kurulu (Australian Accounting Standards Board - AASB) tarafindan tartışmaya ve ilgili tarafların yorumuna açılmıştır (AASB, 2018).Bu konuda izlenecek rotanın 2019 yılı içinde belirlenmesi beklenmektedir.

\subsection{Uluslararası Kuruluşlar ve Birleşmiş Milletler Örgütleri Açısından IPSAS Uygulaması}

Avrupa Komisyonu (EC), Kuzey Atlantik Anlaşması Örgütü (NATO), International Criminal Police Organization (Interpol) gibi devletlerarası kuruluşlar ve Dünya Gıda Programı (WFO), Uluslararası Çalışma Örgütü (ILO) ve Birleşmiş Milletler Çocuk Fonu (UNICEF) gibi Birleşmiş Milletler (BM) örgütleri daha şeffaf ve güvenilir mali tablolar düzenlemek veya önceki kullandıkları muhasebe yönteminde karşılaşmış oldukları teknik sorunlara çözüm bulabilmek amacıyla finansal raporlama alanında bir takım temel reformlara gitmişlerdir. Örneğin; BM Örgütü 1991 yılında ilk kez Birleşmiş Milletler Muhasebe Standartları Sistemi(United Nations System Accounting Standards - UNSAS) adinda bir finansal raporlama standart seti yayınlamıştır (Bergman ve Fuchs, 2017). UNSAS, 2007 yılına kadar 7 kez güncellenmek suretiyle yürürlükte kalmıştır. BM,2006 yılından IPSAS'ın benimsenmesi yönünde karar almıştır. Benzer bir biçimde AB Komisyonu da 2000 yılında başlattığı modernleşme projesi kapsamında yeni finansal düzenlemelere yer vermiş ve 2002 
y1lının sonunda aldığ uygulaması ile birlikte IPSAS'ın benimsenmesine ilişkin bir adım atmıştır.

Tablo 4. Uluslararası Kuruluşlar ve BM Örgütlerinin IPSAS'a Uyum Düzeyleri

Uluslararası Kuruluşlar

IPSAS’a Uyum

ASEAN (Association of South-East Asian Nations)

Common wealth Secreteriat

COE (Council of Europe)

EC (EuropeanCommission)

ESA (European Space Agency)

EUMETSAT (European Organization for the Exploitation of Meteorogical Satellites)

INTERPOL (International Criminal Police Organization)

ITER Organization (International Thermonuclear Experimental Reactor)

NATO (North AtlanticTreaty Organization)

OECD (Organization for Economic Cooperation and Development)

\section{Birleşmiş Milletler Örgütleri}

WFO (World Food Programme)

ICAO (International Civil Aviation Organization), IMO (International Maritime Organization), ITU (International Telecommuncations Union), PAHO (Pan American Health Organization), UNESCO (United Nations Educational, Scientific and
2013 yllından bu yana IPSAS ile uyumlu finansal tablolar kullanmaktadır.

1 Temmuz 2008'den bu yana mali tabloları hazırlamak için kullanılan finansal raporlama standartlarının temelinde IPSAS yatmaktadır. IPSAS uyumlu finansal tablolar 2007 yilından bu yana kullanılmaktadir.

IPSAS benzeri finansal tablolar 2005 yılından bu yana kullanılmaktadır.

2010 yılindan bu yana IPSAS ile uyumlu finansal tablolar kullanmaktadır.

2012 y1lindan bu yana IPSAS ile uyumlu finansal tablolar kullanmaktadır.

2007 yilından bu yana finansal tablolar Interpol'ün kendi finansal düzenlemeleri ve IPSAS ile uyumlu olacak biçimde hazırlanmaktadır. IPSAS ile Interpol Finansal Düzenlemeleri arasında fark bulunduğu zaman Interpol'ün kendi düzenlemeleri esastır. IPSAS ile Interpol'ün düzenlemeleri arasında belirgin farklılıklar bulunmamaktadır.

2008 y1lından bu yana IPSAS düzenlemelerine yönelik finansal tablo yayınlamaktadır.

2008 yilindan bu yana IPSAS benzeri düzenlemeler kullanarak finansal tablo yayınlamaktadır.

Dünyada IPSAS benzeri standartlar kullanan ilk kuruluştur. 2000 y1lından bu yana IPSAS uyumlu düzenlemeler kullanarak finansal tablo düzenlemektedir.

Birleşmiş Milletler Örgütleri arasında IPSAS uyumlu düzenlemeler kullanarak finansal tablo hazırlayan ilk kuruluştur. 2008 yılından bu yana IPSAS'a uyumlu finansal tablo düzenlemektedir.

2010 y1lından bu yana IPSAS'a uyumlu finansal tablo düzenlemektedir. 
Cultural Organization), UNIDO (United Nations Industrial Development Organization), WIPO (World Intellectual Property Organization), WMO (World Meteorological Organization)

IAEA (International Atomic Energy Agency) ve UPU (Union Postale Universelle)

ILO (International Labour Organization), UNHCR (Office of the United Nations High Commissioner for Refugees), UNDP (United Nations Development Programme), UNFPA (United Nations Population Fund), UNICEF (United Nations Children's Fund), UNOPS (United Nations Office for Project Services), UNRWA (United Nations Relief and Works Agency for Palestine Refugees in the Near East), UNJSPF (United Nations Joint Staff Pension Fund), WHO (World Health Organization), UN Women (United Nations Entity for Gender Equality and the Empowerment of Women)

UN (United Nations), FAO (Food and Agriculture Organization), UNWTO (United Nations World Tourism Organization)
2011 yılından bu yana IPSAS'a uyumlu finansal tablo düzenlemektedir.

2012 y1lından bu yana IPSAS'a uyumlu finansal tablo düzenlemektedir.

Kaynak: Deloitte (2017) IPSAS in your Pocket, s 6.

\section{IPSAS'ların IFRS’lerden Farklı Olduğu Hususlar}

\subsection{Genel Bakıș}

IPSAS ile IFRS'in varoluş amaçları aynı olmakla birlikte, düzenlenmekte oldukları sektörler birbirinden farklıdır. IPSAS, odak noktası kendisi ve yatırımcıları açısından kar sağlamak olmayan, belli hallerde bedel karşılığından yapılmamış olan faaliyetlerden oluşan ve esas niyeti kamuya hizmet sunmakta olan kuruluşlara ilişkin düzenlemeler içermektedir. IFRS'in odak noktasında ise tamamen kar elde etme amacında olan kuruluşlar bulunmaktadır.

IPSAS'a göre kamu sektörü kuruluşlarının temel amacı kendisi ve yatırımcıları adına kar etmekten önce kamuya hizmet sunmaktır. Bu nedenle bu tür kuruluşların performans değerlendirmesi kısmen finansal durumlarının, finansal performanslarının ve nakit akışlarının incelenmesi suretiyle değerlendirilebilir. Kamu sektörü kuruluşlarındaki işlemlerin büyük çoğunluğu bedel karşılığında yapılmayan faaliyetlerden, diğer bir deyişle hükümetin doğrudan karşılığını vermeden ya da almadan sunduğu ya da aldığı işlemlerden oluşmaktadır.

IPSAS'a göre bireylerin ya da bir grup bireyin aldıkları hizmetin kalitesi ve düzeyi normal şartlar altında ödemiş oldukları vergilerin düzeyi ile ilişkili değildir. Kişi ya da gruplar belli hizmetleri alabilmek için belli bir masrafa katlanabilir, belli bir ücret ödeyebilir ve/veya özelleştirilmiş bir takım katkılar yapabilirler. Bu tür işlemlerin doğası bedel karşılığında yapılmıyor olmasıdır. Çünkü kişi ya grubun bu işlemlerden sağlayacağı fayda ödenen tutar ile 
tam olarak örtüşmeyebilir. IPSAS bu tür işlemlerin kaydedilmesi ve ölçülmesinin kamu kuruluşu açısından oldukça önemli olduğundan söz etmektedir.

IPSAS ile IFRS'in varoluş amaçları aynı olmakla birlikte, düzenlenmekte oldukları sektörler birbirinden farklı nitelikte oldukları için aşağıda değinilecek bir takım terminoloji ve uygulama farklılıkları ortaya çıkmaktadır.Çalışma kapsamında tespit edilen farklılıklar halihazırda çalışmanın yapıldığı tarih itibariyle yürürlükte olan IPSAS ve IFRS'ler uyarınca belirlenmiş olan farklılıklardır.

Bu bölümde iki düzenleme arasındaki farklar (1) temel farklar, (2) varlık kavramına ilişkin farklar, (3) terminolojik farklar ve (4) uygulama farklılıkları olmak üzere ele alınacaktır.

\subsection{Temel Farklar}

IPSAS ve IFRS arasındaki temel farklılıkları aşağıdaki biçimde gruplamak mümkündür (Ernstand Young, 2013):

\section{(1) Tam bir mali tablolar seti}

IPSAS'larda IPSAS 1 kapsamında düzenlenen mali tablolar seti, (a) finansal durum tablosu, (b) finansal performans tablosu, (c) net varlıklar/özkaynak değişim tablosu, (d) nakit akış tablosu, kamu kuruluşu onaylanmış bütçesini halka sunacaksa bütçe tutarları ile gerçekleşen tutarları gösteren ayrı bir tablo veya mali tablolarda ayrı bir sütün ile (e) mali tablo dipnotlarını sunmak zorundadır (IPSASB, 2006: 37). Buradaki finansal performans tablosu gelir ve gider farkını eksik veya fazla olarak raporlar. Kar/zarar mevhumu ve diğer kapsamlı gelir unsurları yoktur.

Buna karşılık, IFRS'lerde IAS 1 kapsamında yukarıda değinilen finansal performans tablosu sektör farkından dolayı kar veya zararın raporlanmasına odaklıdır. Bu tabloya kar veya zarar ve diğer kapsamlı gelir tablosu denilmiştir. Dönem karına ek olarak diğer kapsamlı gelir unsurları da bu tabloda raporlanır.

(2) Tanımların ve kaydetme kriterlerinin bir parçası olarak "hizmet potansiyeli"

Bir kamu kuruluşuna ilişkin çoğu varlık ya da yükümlülük niteliğindeki miras varlıklar, halkın kullanımına açık parklar gibi unsurlar, kamu kuruluşunun hizmet sunma zorunluluğu nedeniyle ortaya çıkmıştır. IPSAS hizmet potansiyeli kavramını varlık, yükümlülük, gelir ve gider tanımlarının içinde kullanmaktadır. Hizmet potansiyeli, aynı zamanda ekonomik fayda girişi ya da çıkışı yaratmayacak olan unsurların kaydedilmesine ilişkin tamamlayıcı bir kayıt kriteri olarak da sunulmuştur.

\section{(3) Bedel karşılığı olan ve bedel karşılığı olmayan faaliyetler}

Bir kuruluşun diğer kuruluştan fayda sağlamasına rağmen karşılığında aynı düzeyde bir değer elde etmediği ya da hiç değer elde etmediği işlemler"bedel karşıllı̆̆ olmayan

\footnotetext{
${ }^{\mathrm{c}}$ Hizmet potansiyeli IPSAS kapsamında "bir varlığın kuruluşun amacı ile uyumlu olacak biçimde aynı zamanda nakit girişi yaratma zorunluluğu taşımaksızın, mal ve hizmet sunma kapasitesi” şeklinde tanımlanmıştır.
} 
işlemler/faaliyetler" (non-exchange transactions) olarak tanımlanmaktadır. Kamu sektöründe bedel karşılığı olmayan işlemler/faaliyetler oldukça yaygındır. IPSAS bedel karşılığı olmayan işlem/faaliyetlere ilişkin ölçme ve kaydetme kriterlerini düzenlemektedir. IFRS ise düzenlemelerinde bu konuya değinmemiştir.

\section{(4) Devlet teşviklerinden elde edilen gelirin mali tablolara alınması}

Devlet teşviklerinden elde edilen gelire hak kazanıp kazanmadığına (fonların nasıl kullanılacağına ilişkin bir takım kısıtlamalar bulunsa dahi) veya yükümlülük olarak kaydedilen unsurların belirli koşulları yerine getirme zorunluluğuna odaklanır. Belirli koşulların yerine getirilmesi veya bir takım kısıtlamalar bulunması arasındaki ayırım özellikle de bedel karşılığı olmayan işlemlerden/faaliyetlerden elde edilmiş olan gelirlerin mali tablolara alınıp alınmamasına ilişkin kararın verilmesi açısından oldukça önemlidir. IPSAS kapsamında devlet teşviklerinin IFRS'e göre daha erken bir aşamada mali tablolara alındığından söz etmek mümkündür.

$$
\text { Gelir vergisi }
$$

IPSAS kamu sektöründe faaliyet gösteren kuruluşların genel olarak gelir vergisinden muaf olduklarını varsaymaktadır. IPSAS düzenlemelerine göre raporlayan ve aynı zamanda da gelir vergisi mükellefi olan bir kuruluş söz konusu ise, IAS 12 Gelir Vergisi standardının bu konuda referans kabul edilmesi ve gerekliliklerin bu standart uyarınca yerine getirilmesi gerekir.

$$
\text { Konsolidasyonlar, İştirakler, İş Ortaklıkları ve İlişkili Taraflardaki Paylar }
$$

IPSAS'larda 1 Ocak 2017 tarihine kadar konsolidasyonlar IPSAS 6 Konsolide ve Bireysel Finansal Tablolar, iştiraklere ilişkin muhasebe politikaları IPSAS 7 İştiraklerdeki Paylar ve iş ortaklıklarına ilişkin muhasebe politikaları IPSAS 8 İş Ortaklıklarındaki Paylar standardına göre düzenlenmiştir (IPSASB, 2018c: 2466). Bu IPSAS’lar IFRS kapsamındaki eski IAS 27 Konsolide ve Bireysel Finansal Tablolar, IAS 28 İştiraklerdeki Yatırımlar ve IAS 31 İş Ortaklıklarındaki Paylar standartlarında yer alan düzenlemeleri temel almıştır. Bu arada, IFRS'lerde yapılan güncelleme ile IFRS 10 Konsolide Finansal Tablolar, IAS 27 Bireysel Finansal Tablolar, IAS 28 İştirakler ve İş Ortaklarındaki Paylar, IFRS 11 Müşterek Anlaşmalar ve IFRS 12 Diğer İşletmelerdeki Paylara İlişkin Açıklamalar standartlarının uygulanmaya başlaması IPSAS ve IFRS arasında temel farklar oluşmasına neden olmuştur. IFRS 10, IFRS 11 ve IFRS 12'nin uygulanmaya başlamasına ilişkin ortaya çıkan en temel fark konsolidasyona yönelik olarak kontrol unsurunun nasıl belirlendiğine ilişkin olmakla birlikte söz konusu fark IAS 28, IFRS 10, IFRS 11, IFRS 12 standartlarını esas alan IPSAS 34, IPSAS 35, IPSAS 36, IPSAS 37 ve IPSAS 38 standartlarının 1 Ocak 2017'de yürürlüğe girmesiyle ortadan kalkmıştır (IPSASB, 2018c: 2464).

\section{(7) Finansal Araçların Ölçümlenmesi ve Sınıflandırılması}

Finansal araçlara ilişkin ölçüm ve sınıflandırma koşulları açısından IAS 39 Finansal Araçlar: Muhasebeleştirme ve Ölçme standardı IFRS bünyesinde uygulamadan kaldırılmadan öncesindeki dönemlerde IPSAS ve IFRS düzenlemeleri arasında fark bulunmamıştır. IFRS 9 Finansal Araçlar standardının uygulanmaya başlanmasından sonra iki düzenleme arasında 
önemli farklar ortaya çıkmıştır. Diğer taraftan, IFRS 9 standardından esinlenerek IPSAS için hazırlanan IPSAS 41 Finansal Araçlar standardı Ağustos 2018'de yayınlanmış olup 1 Ocak 2022'den itibaren uygulanması beklenmektedir (IPSASB, 2018d: 9). Dolayısıyla o vakte kadar IPSAS ve IFRS arasındaki farkın devam etmesi söz konusudur.

(8) Gerçekleşen ve Bütçelenen Unsurların Raporlanması

IPSAS, kuruluşa ait fiili finansal performans ile onaylanmış bütçeye ilişkin karşılaştırmanın sunulmasını öngörmektedir. Kamu kuruluşunun onaylanmış bütçesi halka açıtır. IFRS düzenlemeleri içinde benzer bir husus yer almamaktadır.

(9) Nakit Yaratmayan Varlıklarda Değer Düşüklüğü

IPSAS düzenlemelerinde, ekonomik fayda yaratma koşulu değil hizmet yaratma potansiyeli uyarınca finansal tablolara alınmış olan varlıklar için değer düşüklüğüne ilişkin düzenlemelere yer vermiştir. IFRS ise tüm varlıkların nakit yaratan varlıklar olduğunu varsaymaktadır. IPSAS 21 Nakit Yaratmayan Varlıklarda Değer Düşüklüğü standardı bu tür varlıkların kullanım değerinin hesaplanmasına ilişkin özel açıklamalar içermektedir.

\section{(10) Özel Sektöre İlişkin Kavramların Eliminasyonu}

IFRS kamu sektörünün özü ile tam örtüşmeyen, hisse bazlı ödemeler, hisse başına kazançlara ilişkin açıklamalar benzeri ekonomik olgulara ilişkin düzenlemeler içermektedir. IPSAS'da IFRS 2 ve IAS 33 doğrultusunda bir düzenleme bulunmamaktadır (IPSASB, 2019: 2). Kamu kuruluşları açısından bu tür bir düzenlemeye ihtiyaç duyulduğunda IFRS referans olarak kabul edilebilir.

(11) IFRS'lerde olup IPSAS’larda Olmayan Standartlar

IPSAS'larda halihazırda IFRS'lerde yer alan IFRS 5 Satış Amacıyla Elde Tutulan Duran Varlıklar ve Durdurulan Faaliyetler, IFRS 6 Maden Kaynaklarının Çıkarılması ve Değerlendirilmesi, IFRS 14 Düzenlemeye Dayalı Erteleme Hesapları, IFRS 17 Sigorta Sözleşmeleri, IAS 26 Emeklilik Fayda Planlarının Muhasebeleştirilmesi ve Raporlanması ile IAS 34 Ara Dönem Raporlama standartlarına henüz yer verilmemiştir (IPSASB, 2019: 2). Bu standartların IPSAS’lara kazandırılması IPSASB’a göre öncelik arz etmemektedir.

\section{IPSAS 18 Bölümlere Göre Raporlama}

IPSAS'da bölümlere göre raporlama IFRS'deki eski IAS 14 standardına dayanmaktadır. IPSAS'da bölümler, hizmet bölümleri ve bölgesel bölümler olarak iki ayrı kategoride ele alınmıştır (paragraf 17). Standarda göre hizmet bölümü bir kamu kurumu/kuruluşunun ya temel amaç ve görevleri ya da belirli faaliyet hedefleri için faaliyet gösteren ve ayırt edilebilen bileşenidir. Bölgesel bölüm yine ayırt edilebilen bir bileşen olmakla birlikte belirli bir coğrafi bölgede yapılanmış ve kurumun/kuruluşun temel amacı doğrultusunda gerçekleştirdiği faaliyetlerini nitelemektedir. IPSAS aynı zamanda bölümlerin sonuçlarının açıklanmasına yönelik bir kural da getirmemiştir. Diğer taraftan, IFRS bünyesinde IFRS 8 Faaliyet Bölümleri standardının yürürlüğe girmesinin ardından IAS 14 Bölümlere Göre Raporlama standardı yürürlükten kalkmıştır. IFRS 8, IAS 14'deki bölüm 
tanımını revize etmiş “faaliyet bölümü” şeklinde yeniden tanımlamıştır (paragraf 2). Faaliyet bölümü tanımı IPSAS'daki bölüm tanımından (1) üzerinden hasılat elde edilebilecek olması ve (2) hakkında ayrı finansal bilginin mevcut olması açılarından farklılaşmaktadır.

IPSAS'lar kapsamında da IFRS 8 standardını esas alan bir IPSAS standardının hazırlanması ve yayınlanması beklenmekte olup bu standardın hazırlanma süreci IPSASB'ın 2019 - 2023 çalışma planı içerisinde önceliklendirilmiş bir konu olarak yer almaktadır.

\section{Üzerinde Çalışılmakta olan IPSAS Projeleri}

IPSAS'larda günceli yakalamak adına IFRS'lerdeki en yeni standartların IPSAS bünyesine kazandırılması için projeler yürütülmektedir(IPSASB, 2019: 2). Nitekim IFRS 13 Gerçeğe Uygun Değerin Ölçümü standardı üzerinde IPSASB Ölçüm Projesi kapsamında, IFRS 15 Müşteri Sözleşmelerinden Hasılat ve IAS 20 Devlet Teşviklerinin Muhasebeleştirilmesi ve Devlet Yardımlarının Açıklanması standartları üzerinde IPSASB Hasılat Projesi kapsamında, IFRS 16 Kiralamalar standardı üzerinde IPSASB Kiralamaları Projesi kapsamında çalışılmaktadır. Dolayısıyla, bu standartlar hazırlanıp yürürlüğe girinceye kadar IPSAS ile IFRS arasındaki farklar devam edecektir.

\subsection{Varlık Kavramına İlişkin Farklar}

(1) IFRS Kavramsal Çerçevesi (2018) uyarınca varlık "geçmişteki olayların bir sonucu olarak işletme tarafından kontrol edilen mevcut bir ekonomik kaynak" şeklinde tanımlanmıştır. Bir kaynağın ekonomik olması o kaynağın kesin hatta muhtemel olmamakla birlikte halihazırda mevcut olması nedeniyle ekonomik fayda üretme potansiyeline sahip olması anlamında kullanılmaktadır. İşletme tarafından kontrol edilebilir olması ise mevcut kaynağın işletmeye bağlı olduğunu göstermektedir. Diğer bir deyişle, işletme o varlığın kullanılması neticesinde varlıktan kaynaklanan ekonomik faydaları elde edecek ise o varlığın işletmenin kontrolünde olduğundan söz etmek mümkündür. Diğer taraftan, IPSAS Kavramsal Çerçevesine göre ise varlık "geçmişteki olayların bir sonucu olarak işletme tarafından kontrol edilen mevcut bir kaynak” biçiminde tanımlanmaktadır.

Gerek IFRS ve IPSAS Kavramsal Çerçevelerinde tanımların özü aynı olmakla birlikte kamu sektörü ve özel sektördeki "kaynak" kavramlarının farklı olması nedeniyle ayrışmaktadır. IPSAS'a göre kaynak, hizmet sunma imkanı tanıyan ya da ekonomik fayda üretme potansiyeline sahip olan, fiziksel bir yapıya sahip olması gerekli olmayan, ekonomik fayda yaratma potansiyeli doğrudan kaynağın kendisinden ya da kaynağı kullanma hakkından (örneğin belli bir konu ile ilgili nakit akışlarını elde etme hakkı) doğan unsurlar şeklinde tanımlanmaktadır. Ekonomik fayda, nakit girişi ya da nakit çıkışında azalma yaratan hususlar biçiminde tanımlanabilir. Hizmet sunma hakkı belli bir malın üretilmesini de kapsamaktadır. Hizmet sunma imkanı, kuruluşun amaçlarını gerçekleştirmeye katkı sağlayacak olan hizmetin sunulma kapasitesini gösterir ve bir kuruluşun nakit girişi yaratmasına gerek olmadan da amaçlarına ulaşabileceğine işaret eder. Rekreasyonel, mirasa, cemaatlere, savunmaya ve diğer unsurlara ilişkin varlıklar hizmet sunma imkanı içeren kamu kuruluşu varlıklarıdır (IPSAS, Kavramsal Çerçeve: 5.9). Bu tür varlıklar üçüncü parti kişi ve kuruluşlara hizmet sunmak için kullanılmaktadır. 
(2) Varlıklar konusunda IFRS ile IPSAS arasındaki farklardan biri, IPSAS'ın gelecekte nakit girişi yaratmayacak olan unsurların da varlık olarak kaydedilmesine izin vermesi ve bir diğer fark ise "geçmişteki olay" kavramından kaynaklanmaktadır. IPSAS'a göre geçmişte gerçekleşen bir olay şu anda kuruluşun bir kaynağın kontrolünü eline geçirmesine, diğer bir deyişle varlık olarak muhasebeleştirilebilecek bir unsurun ortaya çıkmasına neden olur. Kamu sektörü kuruluşları açısından varlıklar, geçmişteki iktidar gücünün kullanılması suretiyle kontrol altına alınmış olan varlıkları kapsayan birtakım bedel karşılığında yapılmamış olan faaliyetler niteliğindeki işlemlerin sonucu olarak da ortaya çıkmış olabilir. Örneğin devletin vergi toplayabilme gücü, varlıkların ortaya çıkmasına neden olan özel kamu gücünün en temel göstergelerinden biridir (IPSAS, Kavramsal Çerçeve: 5.13).

\subsection{Terminoloji Farkları}

Genel olarak IFRS ve IPSAS arasındaki en belirgin farklar, her iki standart setinin kullandığı terminolojiden kaynaklanmaktadır. Söz konusu farklar, aşağıda örneklenmiştir.

(1) IPSAS 41 "Finansal Performans Tablosu” ve "Net Varlıklar (Aktif) /Özkaynak terimlerini kullanırken bu kavramların IFRS 9'daki karşılığ "Kapsamlı Gelir Tablosu” ya da “Bireysel Gelir Tablosu” ve “Özkaynak” biçimindedir.

(2) IPSAS 41 "hasılat" ve "gelir" kavramları arasında bir ayrıştırmaya gitmemiştir. Buna karşı1ık IFRS 9' da bu kavramlar ayrıştırılmış ve "gelir" kavramı "hasılat" kavramına göre çok daha geniş bir kapsamda kullanılmaktadır.

(3) IPSAS 12'de stoklar aşağıdaki biçimde tanımlanmıştır (paragraf 9):

- Üretim sürecinde kullanılacak olan ilk madde ve malzemeler,

- Hizmetlerin ifasında kullanılacak ya da dağıtılacak olan malzemeler,

- İşin normal akışı içinde dağıtım ya da satılmak için elde tutulanlar,

- Üretim sürecinde olan varlıklar.

IPSAS 12'nin stok tanımında "hizmet ifası" ve "kamuya dağıtım" kavramları ön plana çıkmaktadır. Bu kavramlar, IAS 2'de yer almamaktadır. Bu durum, tamamen kamu sektörünün temel amacı olan "kendisi ve yatırımcıları adına kar etmektense kamuya hizmet sunma” temel amacı ile örtüşen bir stok tanımına dayanmaktadır.

(4) IPSAS 18’e (paragraf 9) göre bölüm kamu idaresinin,

Geçmişteki performansının hedeflerine ulaşma anlamında değerlendirilmesi,

Geleceğe yönelik olarak tahsis edilecek olan kaynakların belirlenmesi

amacıyla mali bilgilerin ayrı olarak raporlanmasının uygun olduğu ayırt edilebilir bir faaliyet veya faaliyet grubu olarak tanımlanmaktadır. Burada da "kamuya" vurgu yapılmıştır. 
(5) IFRS kapsamında IAS 41 uyarınca tarımsal faaliyet "Satışa veya geri dönüştürülmeye konu canlı varlıkların tarımsal ürünlere veya farklı canlı varlıklara dönüştürülmesi ve hasat işlemlerinin bir işletme tarafından yönetimi” biçiminde tanımlanmaktadır. Diğer taraftan, IPSAS'da IPSAS 27'nin (paragraf 9) tarımsal faaliyet tanımında ise söz konusu kuruluş bir kamu kuruluşu olduğu ve biyolojik varlığın elden çıkarılması nominal bedel karşılığı ya da bedelsiz dahi olsa bu işlem bir tarımsal faaliyet olarak kabul edildiği belirtilmiştir. Ayrıca, IPSAS bedel karşılığında yapılmayan faaliyetler sonucunda elde edilen biyolojik varlıklara ilişkin de açıklamalarda bulunmaktadır.

(6) IFRS kapsamında geçen “işletmenin sürekliliği” kavramı IPSAS'lar kapsamında IPSAS 14 Raporlama Tarihinden Sonraki Olaylar standına göre süreklilik bir bütün olarak devletin değil, idarenin sürekliliği biçiminde ele alınmaktadır (paragraf 17). Söz konusu standart uyarınca kamu idaresinin faaliyetlerin durdurulması, faaliyetlerin başka bir kuruma devredilmesi ya da kurumun tasfiye söz konusu olmadığı sürece finansal tablolar süreklilik varsayımı altında hazırlanacaktır

İdare, aynı zamanda süreklilik varsayımının geçerli olup olmadığına ait değerlendirmesini yaparken idari yapıda değişiklik olup olmadığını, idarenin performansını, kamu finansmanının varlığını ve devam olasılığı ile yeni finansman kaynakları gibi değişkenleri göz önünde bulundurmalıdır (IPSAS 14,paragraf 19)

(7) IPSAS'daki IPSAS 35 Konsolide Finansal Tablolar standardında IFRS 10 Konsolide Finansal standardından farklı olarak "bağlayıcı sözleşme" adı altında bir düzenlemeden söz edilmektedir. IPSAS 35 'e (paragraf 14) göre bağlayıcı sözleşme "taraflara adeta bir sözleşmeden kaynaklanan yasal haklar da dahil hak ve yükümlülükler veren düzenleme” biçiminde tanımlanmaktadır. IFRS'de benzer bir düzenleme bulunmamaktadır.

\subsection{Uygulama Farklılıkları}

(1) IPSAS 10 cari (current) finansal tabloların yeniden düzenlemesine ilişkin açıklama içermemektedir. Buna karşılık IAS 29'da (paragraf 3,8,9,19,38) bu duruma ilişkin açıklamalar mevcuttur.

(2) IPSAS 12 (paragraf 16) uyarınca, stoklar eğer bedel karşılığında yapılmayan faaliyetler sonucunda edinilmiş ise edinme tarihindeki gerçeğe uygun değeriyle, bedelsiz ya da nominal bedelle sağlanan stoklar ya da bu tür stokların üretimi için elde tutulan stoklar (ilk madde malzeme) maliyet ve cari yenileme maliyetinden düşük olanı ile değerlenmelidir. IPSAS 12 cari yenileme maliyetini "Sahip olunan varlığın raporlama tarihinde edinilmesi durumunda, varlığın edinilmesi amacıyla kamu idaresinin katlanacağı maliyet” biçiminde, maliyet değerini ise "ekonomik varlığın edinilmesi ya da değerinin artırılması amacıyla yapılan ödemeler ve bunlara ilişkin giderlerin toplamı” biçiminde tanımlamıştır.

(3) IPSAS ve IFRS'in finansal araçların sunumuna, muhasebeleştirilmesine ve ölçülmesine ve açıklamalarına ilişkin uygulama farkları bulunmaktadır. IPSAS 28 Finansal Araçlar: Sunum standardı bedel karşılığından yapılmayan faaliyetlerden doğan varlık ve yükümlülüklerin hangi durumlarda finansal varlık ya da finansal yükümlülük olarak 
sunulacağına ilişkin bir "Uygulama Rehberi” sunmaktadır. Buna ek olarak, IPSAS 29 Finansal Araçlar: Muhasebeleştirme ve Ölçme ve IPSAS 41 Finansal Araçlar standartları kapsamında da sağlanan imtiyazlı krediler ${ }^{\mathrm{d}}$ ve bedelsiz ya da nominal değer üzerinden girilen mali garanti sözleşmeleri için de ek uygulama rehberleri bulunmaktadır. Girilen mali garanti sözleşmesinin bedel karşılığından yapılmayan faaliyetlerden kaynaklanıyor olması durumunda IPSAS'a özel bir takım uygulamalar yapılması gerekmektedir. IPSAS 41 aynı zamanda gerçeğe uygun değerin ölçülmesi ve bedel karşılığı olmayan işlem/faaliyetler sonucu ortaya çıkan özkaynağa dayalı finansal araçlar ile de ek uygulama rehberi sunmaktadır.

(4) Yukarıda da değinildiği üzere IPSAS ve IFRS'in varlık tanımları arasındaki fark nedeniyle IPSAS ve IFRS arasında varlıklarda değer düşüklüğü konusunda da fark ortaya çıkmaktadır. IAS 36 Varlıklarda Değer Düşüklüğü standardı, kar odaklı kuruluşların nakit üreten varlıklarındaki değer düşüklügünü ele almaktadır. Buna karşılık, IPSAS'da değer düşüklüğü kamu kesimi kuruluşlarındaki nakit üreten ve nakit üretmeyen varlıklar için iki ayrı standart vasitasıyla ele alınmaktadır. Hatta IPSAS 26 (paragraf 112, BC-12) nakit üreten bir varlığın nakit üretmeyen bir varlığa dönüşmesi için yeniden tasarlanması, ya da tam tersi haller için açıklamalarda bulunmaktadır.

(5) IPSAS ve IFRS'in süreklilik kavramına olan bakış açılarının farklı olduğundan yukarıda daha önce söz edilmiştir. IPSAS 14'e göre artık kamu idaresinin süreklilik varsayımı geçerli değilse, kamu idareleri bu durumu kendi mali tablolarında göstermeleri ve varlık ve yükümlülüklerin defter değerlerinde değişiklik olup olmadığı değerlendirilmesi gereğinden söz edilmektedir (paragraf 22). Buna karşılık, IAS 10 Raporlama Tarihinden Sonraki Olaylar standardında ise eğer süreklilik kavramı geçerliliğini yitirdi ise, finansal tablolara bu varsayım altında alınmış olan tutarların düzeltilmesi yerine, muhasebe esaslarında temel bir değişiklik yapılmasının gereğinden söz edilmektedir.

\subsection{Genel Değerlendirme}

IPSAS'lar ve IFRS'ler arasındaki bazı temel farklara somut olarak yukarıda değinilmiştir. Aşağıda Tablo 5'de ise IPSAS ve IFRS arasındaki benzerlik ve farklılıklar genel konu başlıkları ve ana hatlarıyla görülmektedir. Bu farklar en belirgin farklar olup, her iki düzenleme setinde bulunan tüm farklılıkları içermemektedir. Farklılık/benzerlik düzeylerini temsil eden şekillerin taşıdıkları anlam takip eden biçimdedir:

- İki düzenleme arasındaki minör farklılıklar terminoloji farklarından ve kamu sektörüne özel olarak yapılmış ek yönlendirmelerden kaynaklanmaktadır.

- İki düzenleme arasında kısmi farklar bulunmaktadır. Farklılıklar sınıflandırma, muhasebeleştirme, ölçme ve/veya sunum şartlarına ilişkindir.

İki düzenleme arasında sınıflandırma, muhasebeleştirme, ölçme ve/veya sunum şartlarına ilişin belirgin farklılıklar bulunmaktadır.

\footnotetext{
${ }^{\mathrm{d} I ̇ m t i y a z l ı ~ k r e d i l e r ~ p i y a s a ~ k o s ̧ u l l a r ı ~ a l t ı n d a ~ v e r i l e n ~ v e ~ g e l i s ̧ m e k t e ~ o l a n ~ u ̈ l k e l e r e ~ v e r i l e n ~ k r e d i l e r, ~ o ̈ g ̆ r e n c i l e r e ~}$ verilen öğrenim kredileri, düşük gelirle ailelere verilen ev kredileri vb. kredilerden oluşmaktadır. Bu tür krediler kamu kuruluşları tarafindan verilir.
} 
$1 \quad$ Kuruluşun tabi olduğu düzenlemede söz konusu olaya ilişkin bir standart bulunmamaktadır. Eğer kuruluşun bu tür bir olaya ilişkin bir düzenlemeye ihtiyacı var ise bu ihtiyacını karşılamak için diğer düzenlemeleri referans almalıdır.

Tablo 5. IPSAS ve IFRS Arasındaki Farklılıklar ve Benzerlikler

\begin{tabular}{|c|c|c|c|}
\hline \multirow[t]{2}{*}{ Konular } & \multicolumn{2}{|c|}{ Ele Alınma } & \multirow{2}{*}{$\begin{array}{c}\text { Farklılık/ } \\
\text { Benzerlik } \\
\text { Düzeyi* }\end{array}$} \\
\hline & IPSAS & IFRS & \\
\hline \multicolumn{4}{|l|}{ Finansal Tabloların Sunumu } \\
\hline Finansal tabloların sunumu & + & + & $\nabla$ \\
\hline Nakit akış tabloları & + & + & $\bullet$ \\
\hline $\begin{array}{l}\text { Muhasebe Politikaları, Muhasebe Tahminlerinde Değişiklikler ve } \\
\text { Hatalar }\end{array}$ & + & + & $\bullet$ \\
\hline Finansal tablolarda bütçeye ilișkin bilgilerin sunulması & + & - & 4 \\
\hline $\begin{array}{l}\text { Satış amaçlı elde tutulan maddi duran varlıklar ve durdurulan } \\
\text { faaliyetler }\end{array}$ & - & + & 4 \\
\hline Emeklilik fayda planlarının muhasebeleştirilmesi & - & + & 4 \\
\hline Ara dönem finansal raporlama & - & + & 4 \\
\hline Döviz kurunda meydana gelen değişikliklerin etkisi & + & + & $\nabla$ \\
\hline \multicolumn{4}{|l|}{ Gelir ve Giderler } \\
\hline Gelir & + & + & $\nabla$ \\
\hline İnşaat sözleşmeleri & + & + & $\bullet$ \\
\hline $\begin{array}{l}\text { Bedel karş1lı̆̆ olmayan faaliyetlerden gelirler (vergiler, devlet } \\
\text { teşvikleri, transferler) }\end{array}$ & + & $+* *$ & $\mathbf{\square}$ \\
\hline Gelir vergileri & - & + & 4 \\
\hline Kira sözleşmeleri (leases) & + & + & $\nabla$ \\
\hline Borçlanma maliyetleri & + & + & $\mathbf{\square}$ \\
\hline \multicolumn{4}{|l|}{ Finansal Olmayan Varlıklar } \\
\hline Stoklar & + & + & $\nabla$ \\
\hline Yatırım amaçlı gayrimenkuller & + & + & $\nabla$ \\
\hline Maddi duran varlıklar & + & + & $\nabla$ \\
\hline Maddi olmayan duran varlıklar & + & + & $\nabla$ \\
\hline Tarım & + & + & $\nabla$ \\
\hline Nakit yaratan varlıklarda değer düşüklüğü & + & + & $\nabla$ \\
\hline Nakit yaratmayan varlıklarda değer düșüklüğü & + & - & 4 \\
\hline Maden kaynaklarının araştıılması ve değerlendirilmesi & - & + & 4 \\
\hline \multicolumn{4}{|l|}{ Finansal Olmayan Yükümlülükler } \\
\hline Çalışanlara sağlanan faydalar & + & + & $\mathbf{\square}$ \\
\hline Karşılıklar, koşullu varlık ve koşullu yükümlülükler & + & + & $\vec{v}$ \\
\hline \multicolumn{4}{|l|}{ Grup Muhasebesi } \\
\hline Konsolide ve bireysel finansal tablolar & + & + & $\mathbf{\square}$ \\
\hline İlișkili taraflardaki yatırımlar & + & + & $\nabla$ \\
\hline İș ortaklıklarındaki paylar & + & + & $\mathbf{\square}$ \\
\hline Diğer kuruluşlardaki paylara ilişkin açıklamalar & + & + & $\mathbf{\square}$ \\
\hline İşletme birleşmeleri & - & + & 4 \\
\hline \multicolumn{4}{|l|}{ Finansal Araçlar } \\
\hline Finansal araçlar: sunum & + & + & $\nabla$ \\
\hline Finansal araçlar: Muhasebeleştirme ve ölçme & + & + & - \\
\hline
\end{tabular}




\begin{tabular}{|l|c|c|c|}
\hline Finansal araçlar: açılama & + & + & - \\
\hline Hisse bazlı ödemeler & - & + & $\mathbf{4}$ \\
\hline Sigorta sözleşmeleri & - & + & \\
\hline Gerçeğe Uygun Değerin Ölçülmesi & & & \\
\hline Gerçeğe uygun değerin ölçümü & - & + & $\mathbf{-}$ \\
\hline Dipnot Açılamalarına Odaklanan Standartlar & & & \\
\hline Bölümlere göre raporlama & + & + & $\mathbf{\square}$ \\
\hline İlişkili taraf açklamaları & + & + & $\mathbf{\square}$ \\
\hline Genel kamu sektörüne ilişkin finansal bilginin açıklanması & + & - & $\mathbf{4}$ \\
\hline Hisse baş1 kazanç & - & + & $\mathbf{4}$ \\
\hline Finansal Tablolara İlişkin Düzeltmeler & & & \\
\hline Raporlama tarihinden sonraki olaylar & + & + & $\bullet$ \\
\hline Yüksek enflasyonlu ekonomilerde raporlama & + & + & $\bullet$ \\
\hline
\end{tabular}

*IFRS 9, 10, 11, 12 ve 13'de 2013 ve 2015 yılında meydana gelen değişiklikleri de içermektedir.

**IFRS yalnızca devlet teşviklerine ilişkin düzenlemeler içermektedir.

Kaynak: Ernstand Young (2013) A snapshot of GAAP differences between IPSAS and IFRS

\section{SONUÇ}

$\mathrm{Bu}$ çalışmada, devlet muhasebesine yön veren kayıt yöntemleri kısaca incelendikten sonra söz konusu yöntemlerden tam tahakkuk esasının dayandığı Uluslararası Kamu Sektörü Muhasebe Standartları çalışmanın odak noktasını oluşturmuştur. Ülkeler, devlet muhasebesi uygulamalarında şeffaflılık, hesap verebilirlik ve karşılaştırılabilirlik açısından tam tahakkuk esasına yönelmekte olup IPSAS'ları benimseme veya onlara yakın standartlar ortaya koyma eğilimindedirler.

Diğer taraftan, söz konusu IPSAS'lar IFRS'lere dayanmakta olup içerdiği muhasebe politikaları ve terminoloji kamu sektörüne göre uyarlanarak hazırlanmakta ve yayınlanmaktadır. IPSAS'larIFRS'lerle zamanlama açısından her daim uyum içerisinde değildir. Bunun nedeni, IPSAS'larda güncellemeler geriden geldiğinden IPSAS uygulamasında kamu sektörü uyarlaması hariç bir süre dahi olsa IFRS'den farklılık doğabilmektedir. Örneğin, IFRS'de yürürlükten kaldırılan bir standardın IPSAS'da bir süre daha yürürlükte kalması bu durumun nedenlerinden birisidir.

Aslında IPSASB'ın hedefi IFRS'lerden etkilendiği bütün standartlarda kendi IPSAS metnini, IFRS'deki son sürüm üzerine inşa etmek olmalıdır. Örneğin, IPSAS 1 Mali Tabloların Sunumu gibi bir ana standart önemli ölçüde yayınlandığı Aralık 2006'deki haliyle devam etmekte olup dayandığı IAS 1 sürümü ise Aralık 2003'e aittir. Halbuki bu zaman zarfında IAS 1 standardında meydana gelen değişiklikler vardır ancak bunlar standarda yansıtılmamıştır. Böylece, kamu ve özel sektör standart uygulaması arasında farklar kalmıştır. Kamu sektörüne özgü farklar dışında diğer muhasebe politikaları benzer kılınarak meslek mensuplarına uygulama kolaylığg sağlanabilir.

Bu çalışmada, IPSAS'larar asındaki benzerlik ve farklar genel hatlarıyla ele alınmıştır. IPSAS'larla IFRS'ler arasındaki benzerlik ve farkların ayrıntılı olarak değerlendirilmesi 
amacıyla belli standartlar gruplar halinde incelendiğinde akademik yazına yeni katkılar verilmesi mümkündür.

\section{KAYNAKLAR}

AASB (2015), AASB 123 Borrowing Costs, https://www.aasb.gov.au/admin/file/content 105/c9/AASB123_08-15.pdf (Erişim Tarihi: 26.02.2019)

AASB (2018), The AASB's Approach to International Public Sector Accounting Standards. https://www.aasb.gov.au/admin/file/content105/c9/ITC41_08-18.pdf（Erişim Tarihi:26.02.20 19)

ACCA (2017), The Association of Chartered Certified Accountants IPSAS implementation: Current Status and Challenges, https://www.accaglobal.com/content/dam/ACCA_ Global/Technical/pubsect/pi-IPSAS-implementation-current-status-andchallenges.pdf (Erişim Tarihi:26.02.2019)

Aggestam-Pontoppidan, C., Anderneck, I. (2015), Interpretation and Application of IPSAS, John Wiley \& Sons

Arslan A.(2011), Kamu Sektörü Uluslararası Muhasebe Standartları ve Türkiye Uygulaması. https://www.dunya.com/gundem/kamu-sektoru-uluslararasi-muhasebe-standartlariipsasvetur kiye-haberi-156501 (Erişim Tarihi: 11.05.2018)

Bellanca, S., Vandernoot, J. (2013), “Analysis of Belgian Public Accounting and Its Compliance with International Public Sector Accounting Standards (IPSAS) 1, 6 and 22”, International Journal of Business and Management, 8(9).doi:10.5539/ijbm.v8n9p122

Bergmann, A., Fuchs, S. (2017), “Accounting Standards for Complex Resources of International Organizations”, Global Policy, Volume 8, Issue S5, pp-26-35

Besteliu, N., E. (2018), "Ways of taking over and operationalizing the International Public Sector Accounting Standards (IPSAS) - Essential milestones in this process”, https://search.proquest.com/docview/2043180894/fulltextPDF/1CEE9ED6AAAB4E AFPQ/1? accountid=15426 (Erişim tarihi:21.01.2019)

Christiaens, J., Vanhee, C., Rossi ,F. M., Aversano, N., Cauwenberge, P. (2015), “The effect of IPSAS on reforming governmental financial reporting: an international comparison”, International Review of Administrative Sciences, Vol. 81(1) pp.158177. 
Czech Republic Supreme Audit Office (2018), Press Release. https://www.nku.cz/en/formedia/press-releases/international-accounting-standards-2016-are-translated-intoczech--thanks-to-the-sao-and-other-professionals-id9522/(Erişim Tarihi: 22.01.2019)

DMSK (2018), Turkish Public Accounting Reform \& Harmonization of International Standards.http://www.dmsk.gov.tr/upload/Turkish\%20Public\%20Accounting\%20Re form $21 \% 2002 \% 202018 . p d f$ (Erişim Tarihi: 26.02.2019)

Deloitte (2017), IPSAS in your Pocket, s 6. https://www.iasplus.com/en/publications/publicsector/ipsas-in-your-pocket-2017 (Erişim Tarihi: 15.01.2019)

Ernst and Young (2012), Overview and comparison of public accounting and auditing practices in the $27 \mathrm{EU}$ Member States ,Prepared for Eurostat, Final Report, p.78 https://ec.europa.eu/eurostat/documents/1015035/4261806/study-on-publicaccounting-and-auditing-2012.pdf/5ad43e2b-2ba7-4b05-afab-d690fc2ad9dd (Erişim Tarihi: 15.01.2019)

Ernst and Young (2013), A snapshot of GAAP differences between IPSAS and IFRS. https://www.ey.com/Publication/vwLUAssets/GAAP_differences_between_IPSAS_ and_IFRS/\$FILE/IPSAS_Vs_IFRS_AU1506.pdf (Erişim Tarihi: 15.01.2019)

Ernst and Young (2017), Collection of additional and updated information related to the potential impacts of EPSAS, EPSAS Working Group. https://ec.europa.eu/eurostat/documents/64157/4375784/European+Public+Sector+A ccounting+Standards+\%28EPSAS\%29/33209095-65b3-4c80-8b94-10c9a76aec9c (Erişim Tarihi: 15.01.2019)

EUROSAT (2018), https://ec.europa.eu/eurostat/web/government-financestatistics/excessive-deficit-procedure/edp-notification-tables (Erişim Tarihi: 15.01.2019)

Feschiyan, D. (2010), “International Public Sector Accounting Standards in Bulgaria”, Paper presented at 2nd Balkans and Middle East Countries Conference on Auditing and Accounting History, Conference Proceedings, Vol. II p. 1557.

Fisher, L. (2018). "European Countries on the path to IPSAS", International edition of Accounting and Business magazine. https://www.accaglobal.com/in/en/member/ member/accounting-business/2018/03/insights/european-ipsas.html (Erişim Tarihi: 15.01.2019) 
Giuseppe G., Sara Giovanna Mauro \& Jarmo Vakkuri (2018), “Converging and diverging pressures in PBB development: the experiences of Finland and Sweden”, Public Management Review, 20:12, 1836-1857, DOI: 10.1080/14719037.2018.1438500

Gökçen, G. (2003), Devlet Muhasebesi: Teori Uygulamalar ve Öneri, Türkmen Kitabevi, İstanbul

IPSASB (2006), IPSAS 1 Presentation of Financial Statements. https://www.ifac.org/system/ files/publications/files/ipsas-1-presentation.pdf, (Erişim Tarihi: 15.07.2018).

IPSASB (2014a), A Closer Look at: Switzerland, https://www.ifac.org/system/files/ uploads/IPSASB/IPSASB-A-Closer-Look-At-Switzerland2.pdf (Erişim Tarihi: 15.01.2019)

IPSASB (2014b), A Closer Look at: Malta, https://www.ifac.org/system/files/uploads/ IPSASB/A-Closer-Look-at-Malta.pdf (Erişim Tarihi: 15.01.2019)

IPSASB (2011), Key Characteristics of the Public Sector with Potential Implications for Financial Reporting Exposure Draft. https://www.ifac.org/system/files/ publications/exposure-drafts/IPSASB_ED_Key-Characteristics-of-Public-Sector.pdf (Erişim Tarihi: 03.11.2018)

IPSASB (2014a), A Closer Look at: Switzerland, https://www.ifac.org/system/files/ uploads/IPSASB/IPSASB-A-Closer-Look-At-Switzerland2.pdf (Erişim Tarihi: 15.01.2019)

IPSASB (2014b), A Closer Look at: Malta, https://www.ifac.org/system/files/uploads/ IPSASB/A-Closer-Look-at-Malta.pdf (Erişim Tarihi: 15.01.2019)

IPSASB (2018a), IPSAS Adoption and Implementation. https://www.ipsasb.org/adoptionand-implementation (Erişim Tarihi: 03.11.2018)

IPSASB (2018b), International Public Sector Accounting Standards Board https://www. iasplus.com/en/resources/global-organisations/ipsasb.(Erişim Tarihi: 02.11.2018)

IPSASB (2018c), Handbook of International Public Sector Accounting Pronouncements Volume III, International Federation of Accountants, New York.

IPSASB (2018d), IPSAS 41 Summary-Financial Instruments. https://www.ifac.org/ system/files/publications/files/IPSAS-41-Financial-Instruments-At-a-Glance.pdf (Erişim Tarihi: 26.02.2019) 
IPSASB (2019), IPSAS - IFRS Alignment Dashboard March 2019. https://www.ifac.org/system/files/uploads/IPSASB/Agenda\%20Item\%201.7\%20IPS AS\%20IFRS\%20Alignment\%20Dashboard_March\%202019\%20\%20revised\%20\%281\%29.pdf (Erişim Tarihi: 31.03.2019)

Jorge S., (2015), Public Sector Accounting and Auditing in Portugal içinde: Public Sector Accounting Edited by Brusca I., Caperchione, E., Cohen, S., Rossi F. M., Public Sector Accounting and Auditing in Europe: The Challenge of Harmonization, pp.173-186

Karaarslan, E. (2004), Ülkemizde Devlet Muhasebesinin Serüveni. Sayıştay Dergisi, 54.

Karaarslan, E. (2005), Devlet Muhasebesi Olgusu ve Ülkemizde Devlet Muhasebe Standartları, TÜRMOB Yayınları, Ankara

OECD (2012), Report to the Swedish Government: Comparison with international accounting standards etc., p.7, https://www.oecd.org/gov/budgeting/Sweden\%20\%20ESV\%20report.pdf (Erişim Tarihi: 15.01.2019)

Otrusinava, M., Pastuszkova, E. (2013), “Transformation process of state accounting to accrual basis accounting in conditions of the Czech Republic”, Acta Universitatis Agriculturae et Silviculturae Mendelianae Brunensis, 2013, LXI, No. 7, pp. 25932602

Polzer, T., Grossi, G., Reichard, C. (2017), “Adoption of IPSAS in National Accounting Reforms. Country specific Reactions to Global Accounting Standards in Selected European Countries”, Paper for Panel G1 at the 21. IRSPM Conference, Budapest, Abstract, p. 13

Polzer,T., Meyer, R., Höllerer, M., Seiwald, J., (2016), “Institutional Hybridity in Public Sector Reform: Replacement, Blending, or Layering of Administrative Paradigms”, Research in the Sociology of Organizations, 48B, pp.69-99

PSAB (2011), Consultation Paper - Characterictics of Public Sector Entities, http://www.frascanada.ca/standards-for-public-sector-entities/documents-forcomment/item52207.pdf (Erişim tarihi 03.12.2018)

Yanık, S. S. ve Öztürk, C. (2018), "Devlet muhasebesinde muhasebe sistemleri ve tam tahakkuk sisteminin DMS 1 - mali tabloların sunulması standardı açısından değerlendirilmesi”, Muhasebe Bilim Dünyası Dergisi, 20 (Özel Sayı), ss.1007-1029 